\title{
Ülkelerin Faktör Yoğunlukları Bakımından Rekabet Gücünün Ölçümü: BRICS-T Özelinde Karşılaştırmalı Bir Analiz
}

\author{
Measurement of Competitiveness in Terms of Factor Densities of Countries: A \\ Comparative Analysis for BRICS-T
}

\author{
Ali ÇELIKK, Türkiye, alicelik6209@gmail.com
}

\begin{abstract}
Öz: Bu çalışmada, 1995-2017 dönemleri arasında BRICS ve Türkiye'nin ihracat yapıları faktör yoğunlukları bakımından analiz edilmiştir. Rekabet gücünün analizinde AKÜ (Açıklanmış Karş̧laş̧ırmalı Üstünlükler) yararlanılmış ve veriler Birleşmiş Milletlerin (UN) Comtrade veri tabanından derlenmiştir. Ayrıca gerekli hesaplamalar SITC Rev. 3 iki haneli ürün grubu kapsaminda hesaplamalar yapllmıştır. Buna göre, emek yoğun mallarda Hindistan, Çin ve Türkiye karșllaștırma üstünlüklerde rekabet avantajina sahipken yıllar itibariyle emek yoğun malların karșllaștırmalı üstünlüklerinde azalma meydana gelmiştir. Ancak yinede emek yoğun sektörler Hindistan, Çin ve Türkiye için rekabet edebilirliği en yüksek sektörler olduğu tespit edilmiştir. Söz konusu ülkelerin sermaye yoğun mallarındaki görünüme bakıldı̆̆ında, Brezilya, Rusya ve Türkiye ekonomilerinin sermaye yoğun malların üretiminde ve ihracatında zayı f bir karssllasstırmalı üstünlüğe sahiptirler. Ancak Brezilya ekonomisi, sermaye yoğun mallardaki karsllaștırmalı üstünlüğ̈̈nü 2010 yll itibariyle kaybetmişstir. G.Afrika ise sermaye yoğunluk mal grubunda orta dereceli bir karşllaş̧trmalı üstünlüğe sahip olduğu gözlenmektedir. Bununla birlikte, Rusya ve Çin için sermaye yoğun mallardaki rekabet avantajı yllar itibariyle gerilemişken, Hindistan ve Türkiye'nin sermaye yoğun malların üretimi açısından nisbi anlamda kazanımlar elde ettiği tespit edilmişstir. Hammadde yoğun mallardaki karşılaştırmalı üstünlük veya rekabet gücüne Rusya'nın güçlü bir rekabet avantajı olduğu, Brezilya ve G.Afrika'nın orta dereceli bir rekabet avantajı olduğu tespit edilmiştir. Kolay taklit edilen Ar-Ge bazlı malların rekabet gücü görünümü incelendiğinde, Çin ekonomisinin 2000 yllndan itibaren bu alanda zaylf üstünlük düzeyinde olsa da rekabet avantajı sağlamaya başladığı görülmüsşür. Zor taklit edilen Ar-Ge bazlı mallarda ise 2010 yllında Çin zayıf üstünlük düzeyinde rekabet avantajı sağlarken, diğer ülkelerin bu tür mal gruplarında karșılaștırmalı üstünlükleri gözlenmemiștir. Çalıșmada yapılan analizlerde elde edilen bulgulara göre, BRICS ve Türkiye ekonomilerinin kolay ve zor taklit edilen Ar-Ge bazlı malların ihracatındaki açıklanmıs karşılaştırmalı üstünlük katsayılarının nispi olarak düşük olduğu görülmektedir. Bu da söz konusu ülkelerin genel olarak Ar-Ge içerikli malların ihracatında rekabet dezavantajına sahip olduğunun göstergesidir. Ancak, Çin bu ülke grupları arasında Ar-Ge içerikli mal ihracatı bakımindan karşılaştırmalı üstünlüklerinde görece yükselme trendi sergilemiştir. Ancak Türkiye, Ar-Ge bazlı mal ihracatı ve rekabet gücü bakımından söz konusu ülke grubu içinde en kötü konumdan olan ülkelerden biridir. Türkiye’nin bu alanlara yapacağl yatırım ve teşviklerin uluslararası düzeyde rekabetçi olması noktasında olumlu yansımalarının olacağı önerilmektedir.
\end{abstract}

Anahtar Kelimeler: Faktör Yoğunlukları, Rekabet Gücü, Açıklanmış Karşılaştırmalı Üstünlükler, BRICS, Türkiye

Abstract: In this study, the export structure of BRICS and Turkey were analyzed in terms of factor densities for the period between 1995 and 2017. RCA(Revealed Comparative Advantage) was used in analysis competitiveness and the data were compiled from Comtrade database of United Nations $(U N)$. In addition, the calculations required SITC Rev. 3 were made within the scope of two-digit product group. Accordingly, labor-intensive goods in India, China and Turkey over the years while labor-intensive goods competitive advantage in comparison superiority of the decrease occurred in comparative advantage. But still labor-intensive industries in India, China and Turkey have been identified for competitiveness is the highest sectors. Looking at the outlook for capital-intensive goods of these countries, Brazil, Russia and in the production and export of capital-intensive goods have a weak comparative advantage of Turkey's economy. However, the Brazilian economy lost its comparative advantage in capital intensive goods in 2010. In G. Africa, it is observed that capital density has a moderate comparative advantage in the group of goods. However, Russia and China for competitive advantage in capital-intensive goods from one year to regressed, meaning gains in India and Turkey in terms of the relative production of capitalintensive goods have been found to have achieved. Russia has a strong competitive advantage over comparative advantage or competitiveness in raw materials, and Brazil and South Africa have a moderate competitive advantage. When the competitive power of $R \& D$ based goods is examined, it is seen that the Chinese economy has started to provide competitive advantage even though it has a weakness level in this area since 2000 . While $R \& D$ based goods which were hardly imitated provided competitive advantage in China in 2010, the comparative advantages of other countries were not observed. According to the findings obtained in the assays performed in this study, and Turkey BRICS described in the easy and difficult economy it imitated $R \& D$ based export commodities appears to be relatively low comparative quality factor. This indicates that these countries have a competitive disadvantage in the export of goods with $R \& D$ content in general. However, China exhibited a relative uptrend in comparative advantages in terms of exports of $R \& D$ based goods among these country groups. Turkey, however, exports of goods and $R \& D$-based competition exists in terms of power is one of the countries with the worst position in the group of countries. Turkey would be a positive reflection on the point of being competitive at the international level and encourage investments to be made in these areas is recommended.

Keywords: Factor Densities, Competitiveness, Revealed Comparative Advantage, BRICS, Turkey

\section{Giriş}

Dünya ekonomisi, küreselleşme ve teknolojik gelişme dalgasıyla birlikte önemli değişimlere ev sahipliği yapmıştır. Bu değişimler, ülkeler arasındaki sınırları bertaraf ederek, gerek firmalar ve endüstriler gerekse ülkeler bazındaki rekabeti hiç olmadığı ölçüde arttırmıştır. Rekabetçi ortamın varlığı altında firmaların, endüstrilerin veya ülkelerin temel motivasyon kaynağı ise uluslararası rekabetten değer transfer etme ve daha fazla katma değer elde etmektir. Küreselleşmeyle birlikte yalnızca firmalar ve endüstrilerin değil, aynı zaman ülkeler arasındaki rekabet edilebilirliğin yani rekabet gücünün önemi de artmaktadır.

Günümüzde rekabet gücü kavramı önem kazanarak bir ülkenin dünya mal ve hizmet ticaretinde sahip olduğu payı göstermek için kullanılmaktadır. Rekabet gücü kavramı aslında sadece ülkeler için değil, firmalar ve endüstriler içinde geçerlidir. Ancak küreselleşen dünyada firma ve endüstrilerin dış ticarete açık olması ve bağlı oldukları ülkeleri temsil 
etmeleri nedeniyle ulusal rekabet gücü daha fazla önem kazanmıştır. Rekabet gücünün belirleyicilerini fiyat ve fiyat dışı unsurlar olarak incelemek mümkündür. Döviz kuru ve birim işgücü maliyetleri fiyat rekabetini oluştururken; kalite, makroekonomik ortam, altyapı, pazarlama, teknoloji, beşeri sermaye vb. ise fiyat dışı faktörleri oluşturmaktadır (Şahin, 2015: 242).

Ülkemizde son yıllarda yapılan çalışmalar, yasal düzenlemeler ve alınan önlemler ile Türk ekonomisinin uluslararası rekabet gücünün artırılması ve başta Gümrük Birliği olmak üzere Avrupa Birliği ile bütünleşme süreci amaçlanmıştır. 1990'lı yıllarda başlayan hızlı küreselleşme süreci, teknolojideki baş döndüren gelişmeler, ulusal pazardan çok uluslararası pazardan pay kapma yarışını hızlandırmıştır.

Küresel dünyanın dışında kalmamak, sürekli büyüyen pazarda, pazar payını arttırmak veya en azından pazar payını korumak için firsat ve avantajlardan yararlanmak, firmalar ve ülkeler için temel amaçlar arasında yer almaktadır. Bu amaç doğrultusunda her geçen gün daha fazla sayıda firma uluslararası alana açılma ve rekabetçi olabilme ihtiyacı hissetmektedir. Bu rekabet ortamında firmalar, endüstriler ve ülkeler birbirileriyle sürekli yarış halindedir (Altay ve Gürpınar, 2008: 259).

Literatürde rekabet gücünün ölçümünde Balassa (1965) tarafindan ortaya atılan Açıklanmış Karşılaştırmalı Üstünlükler (AKÜ) endeksi ve türev endeksler kullanılmaktadır. Bu çalışmada ilk olarak rekabet gücü kavramından ve ölçüm yöntemlerinden bahsedilmiştir. Daha sonra çalışmada, 1995-2017 dönemleri için BRICS (Brezilya, Rusya, Hindistan, Çin ve Güney Afrika) ve Türkiye'nin faktör yoğunlukları bakımında ihracat yapıları analiz edilmiştir. BRICS ülkelerinin seçilme nedeni, dünyanın yükselen piyasaları olarak kabul edilen bu ülkelerin dünya katma değerinden aldığı payın giderek artmasıdır. Faktör yoğunlukları bakımından (SITC) rekabet gücünü ölçmek amacıyla Açıklanmış Karşılaştırmalı Üstünlükler Endeksi (AKÜ) kullanılmıştır. Çalışma, Türkiye ve BRICS ülkelerinin faktör yoğunlukları bakımından rekabet gücünü karşılaştırma olanağı vererek literatüre katkıda bulunmayı ve katma değerli üretimin arttırılması yolunda politika önerisi geliştirmeyi amaçlamaktadır.

\section{Kavramsal Çerçeve}

Rekabet, esasen kapitalist üretim biçimi altında tam olarak anlamını bulmuş bir kavramsallaştırmadır. Ulusal rezervlerdeki değerli maden stoğundaki niceliksel birikimi zenginliğin asıl kaynağı sayan merkantalizm dönemi, aynı zamanda uluslararası rekabetin sınırlandırıldığı kapalı bir ekonomik modelin egemen olduğu bir dönemdi. Savaş ve yağma koşulları veri kabul edildiğinde tüccarlar yoluyla yapılan ticaret, servet biriktirmenin yegane yöntemiydi. Ancak hem ticaretin boyutunu genişlemesi, hem üretim tekniğindeki ilerlemeler sanayi devrimleri çağını başlatmıştır. Makineli üretime geçişle birlikte devasa ölçeklerde gelişen üretim ve oluşan gönenç dönemi, serbest rekabetin koşullarını yarattığg ileri sürülmektedir. Belirtildiği gibi sermayenin çevrimsel konjonktürü, aynı zamanda rekabet koşullarının da belirleyicisi konumunda bulunmaktadır. Tekil sermayelerin azami kar arayışlarının sonucu olan rekabet, hem ulusal hem uluslararası düzeyde hareketinin önünde herhangi bir engel olmadığı takdirde kar iştihanı kabartma durumundadır. Böylece ulusal sermayeler için rekabet güçlerinin ölçümünü yapmak, uluslararası iş bölümündeki konumları, diş ticaret yapıları ve faktör yoğunluklarının tespiti açısından önem arz etmektedir

Ancak rekabet ölçüm türlerine geçmeden önce, rekabet gücü kavramı ele alınmalıdır. Rekabet gücü konusu üzerine literatürde çok sayıda tanım mevcuttur. Fakat oldukça farklı bağlamlarda tartışılmaktadır. Atik (2015: 14) rekabet gücü kavramı üzerine ortak bir tanımlamanın olmamasının nedenlerini şu şekilde sıralamıştır.

- Rekabet gücü firma, sektör ve ülke bazında değerlendirilerek farklı biçimde tanımlamaktadır.

- Ülkelerin rekabet gücünün belirlenmesinde farklı ölçütler kullanılabilir.

- Rekabet gücü mikro ya da makro açıdan bakılabilir.

Uluslararası rekabet gücü için firma, sektör, ülke bazında mukayeseler yapılmaktadır. Bu çerçevede, mikro düzeyde yapılan rekabet gücü tanımı firma ve sektörleri kapsarken, makro düzeydeki rekabet gücü tanımının içine ülke boyutu dahil edilmiştir. Uluslararası rekabet gücü denince genelde ilk olarak akla ülke seviyesinde rekabet gücü gelmesine rağmen, aslında firma veya sektörel bazda rekabet çalışmalarının yapılmasının daha anlamlı olabileceği tartışılmaktadır. $\mathrm{Bu}$ tartışmalarda uluslararası rekabet gücü konusunun sadece firmalar veya sektörler açısından zaruri olduğu belirtilmektedir. Bu bağlamda, uluslararası piyasalarda rekabet edenin ülke değil, firmalar olduğuna dikkat çekilmelidir (Bedir, 2009: 13). Firma düzeyinde rekabet gücü, rakiplerine göre daha düşük maliyetle üretim, nitelikli ürün ve kaliteli hizmet düzeyi üzerinden ortaya konulmaktadır. Mikro temelli bir diğer rekabet gücü tanımı olan sektör düzeyindeki rekabet gücü, daha çok sektörlerin verimlilik düzeyleri, ticaret performansları, inovasyon ve teknolojik gelişmeye uyum sağlama kabiliyetinin bulunması biçiminde tanımlanmaktadır (Porter, 1990).

Porter (1990) ülkelerin karşılaştırmalı üstünlüklerinin (rekabet gücünün) belirleyicilerini ‘'Rekabet Elması Modeli', yardımıyla açıklamıştır; 


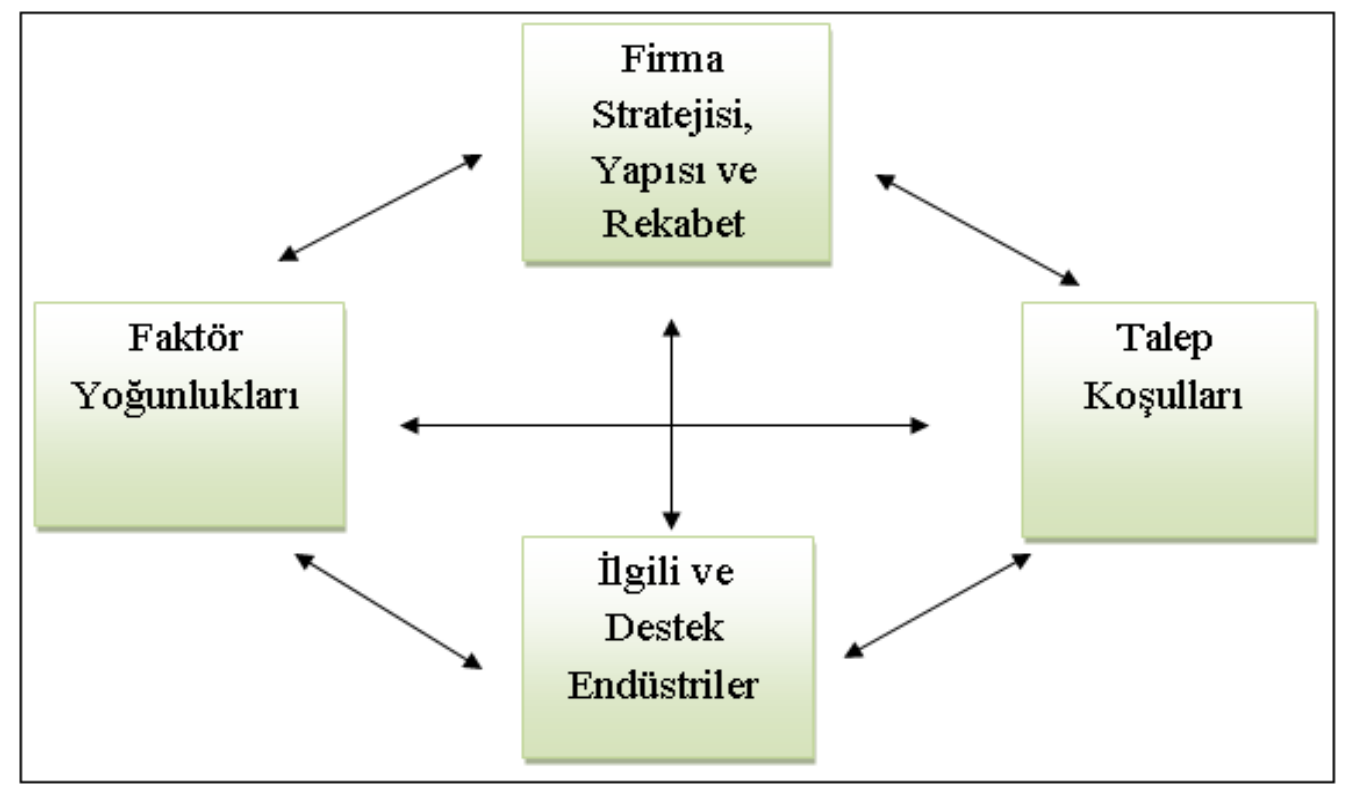

Şekil 1: Rekabet Elması Modeli

Kaynak: M. Porter, The Competitive Advantages of Nations, 1990, s. 78, http://www.economie.ens.fr/IMG/pdf/porter_1990_the_competitive_advantage_of_nations.pdf.

Kibritçioğlu (1996)'na göre, uluslararası rekabet gücünün ülke düzeyinde hesaplanması neredeyse tamamen anlamsızdır. Gerçi ülkeler ve hükümetler açısından endüstrilerinin veya firmalarının uluslararası rekabet gücüne sahip olmaları, üretimde uzmanlaşma, istihdam ve dış ticaret dengesi açısından oldukça önemlidir. Ancak, uluslararası rekabet gücü sorunu yalnızca firmalar bakımından yaşamsal bir sorundur. Zaten ülkelerin birbirleriyle olan rekabeti, ürettikleri ürünlerin fiyat ve kalitesine dayalı değildir. Ülkeler (hükümetler) mal, hizmet ve sermaye hareketleri bakımından giderek küreselleşen bir dünyada uygun bir yatırım ortamı sunarak daha fazla yabancı sermaye çekebilmek açısından birbirleriyle rekabet ederler. Özetle, ülkeler bakımından söz konusu olabilecek olan, sadece bir tür kuruluş yeri rekabetidir (Kibritçioğlu 1996: 3; 1998). Ülkelerin rekabet gücü, Ar-Ge faaliyetleri, verimlilik, teknoloji yoğun malların üretilmesi ve uzman işgücünün varlığına bağlıdır (Çivi, 2001: 25).

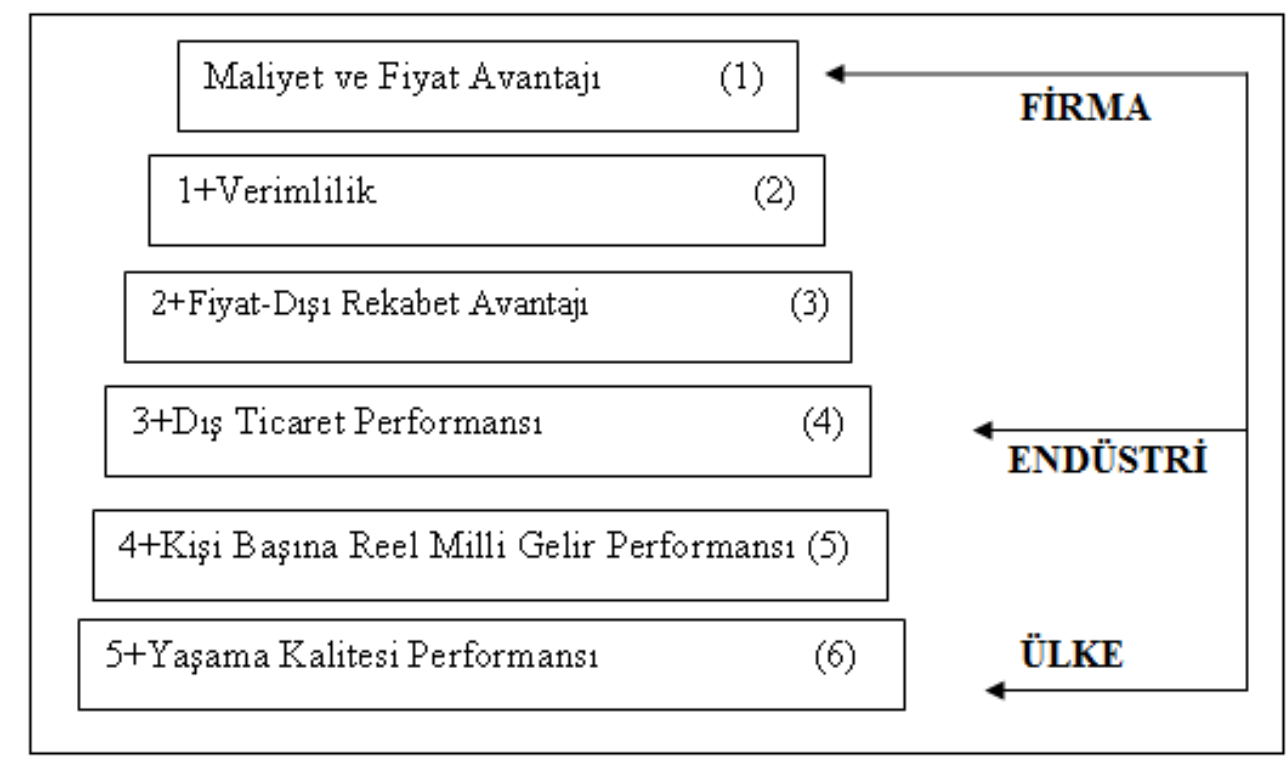

Şekil 2: Rekabet Gücü Kavramları Piramidi

Kaynak: Aktan ve Vural, 2004: 7 
Şekil 2'deki rekabet gücü piramidine bakıldığında, firma düzeyindeki rekabet gücünden uluslararası düzeye doğru gidildikçe incelenen konu sayısının genişlediği görülmektedir. Maliyet ve fiyat avantajı, verimlilik ve fiyat dışı rekabet firma düzeyindeki rekabet gücünü yansıtırken, buna diş ticaret performansı eklenmesiyle endüstri düzeyindeki rekabet gücünü ifade etmektedir. Bütün bunlara kişi başına reel milli gelir performansı ve yaşam kalitesi performansı dahil edildiğinde ise uluslararası rekabet gücü kavramına ulaşılmaktadır. Bu süreç aynı zamanda mikro temelden makro boyuta geçişi de ifade etmektedir (Şahin, 2016: 710).

Rekabet gücünü belirleyen etkenler firma içi etkenler ve firma dışı etkenler olarak iki kategoride toplanmaktadır. Firma içi etkenler arasında, firmanın ürettiği malın kalitesi, maliyeti ve fiyatı önem taşımaktadır. Maliyetler arasında ise işgücü maliyeti, sermaye maliyeti, ithalat maliyeti, vergi maliyeti, sosyal güvenlik maliyeti ön plana çıkmaktadır. Bunun dışında verimlilik, kaynakların etkin kullanımı, firmalarda kullanılan bilgi teknolojisi, yenilikçilik ve yaratıcılık gibi faktörler rekabet gücünü belirleyen firma içi diğer etkenler arasında yer almaktadır. Rekabet gücünü belirleyen firma dışı başlıca etkenler olarak firmanın faaliyette bulunduğu sektörlerdeki rekabet yoğunluğu, döviz kurları, yabancı sermaye, doğal kaynaklar, mali piyasaların yapısı, uluslararası ticaret ve hukuk sistemi yer almaktadır (Aktan ve Vural, 2004: 21) ${ }^{1}$.

$\mathrm{Bu}$ bağlamda, uluslararası ticaret teorisinde çeşitli yaklaşımlar ortaya çıktığı gözlenmiştir. Mutlak Üstünlükler Teorisi, Karşılaştırmalı Üstünlükler Teorisi, Faktör Donanımları Teorisi ve 1960 sonrası popülerlik kazanan Modern D1ş Ticaret Teorileri en bilinen örnekler olarak sıralanabilir. Ancak iktisat araştırmalarının geneli ülkelerin rekabet gücü ölçümünde karşılaştırmalı üstünlükler temelinde geliştirilen endeksleri baz almaktadırlar. Rekabet gücünün ölçülmesi amacıyla geliştirilen çok sayıda endeks söz konusudur. Bu çalışmada en yaygın kullanılan endekslerin teorik arka planı ele alınmıştır.

Açıklamalı Karşılaştırmalı Üstünlükler (AÇÜ) endeksi ve bu endeks yardımıyla uluslararası rekabeti ölçmeye yönelik ilk çaba 1958 yılındaki çalışması ile Liesner'in olmuştur (Liesner, 1958). Ancak Balassa 1965 yılında AÇÜ endeksine yeni bir nitelik kazandırmıştır. Açıklanmış karşılaştırmalı üstünlük katsayısı, ihraç edilen mal grubundaki rekabet gücünü ticaret sonrası verilere dayalı olarak ölçmektedir. Karşılaştırmalı üstünlügün altında yatan kaynakların belirlenmesinden ziyade, ülkenin belli mallarda (sektörlerde) karşılaştırmalı üstünlüğe sahip olup olmadığını ortaya koymaya çalışan AKÜ endeksi; herhangi bir malın(sektörün) ülkenin toplam ihracatındaki payının, söz konusu(malın) sektörün dünyanın (bölgenin) toplam ihracatındaki payını ifade eder.

"'j', ülkesinin ' 't'” döneminde ' $k$ ' malındaki (sektöründeki) açıklanmış karşılaştırmalı üstünlük (AKÜ) katsayısı Balassa tarafından aşağıdaki gibi formüle edilmiştir (Balassa, 1965:99-123)

$A K \ddot{U}_{k t}^{j}=\frac{x_{k t}^{j}}{x_{t}^{j}} / \frac{x_{k t}^{w}}{X_{t}^{w}}$

(RCA) AKÜ endeksinin pay kısmı, malın(sektörün) ulusal ihtiyaçtaki payını (\%); payda kısmı ise, söz konusu malın(sektörün) dünya toplam ihracatındakini payını ifade etmektedir (Mykhnenko, 2005, 27). Buna göre, RCA (AKÜ) katsayısının birden büyük olması, ülkenin söz konusu malın ihracatındaki rekabet avantajına işaret etmekteyken, birden küçük olması ise rekabet söz konusu malın ihracatındaki dezavantajlı durumu göstermektedir. Ülkelerin hangi sektör ve mal grubunda uluslararası rekabet avantajına ya da dezavantajına sahip olacağını saptayan açıklanmış karşılaştırmalı üstünlük katsayısı, ülkelerin rekabet gücünü karşılaştırırken dört kategori altında sınıflandırmaktadır (Hinloopen ve Marrewijk, 2000: 8).

1. Kategori $=0<\mathrm{AKÜ} \leq 1 ;$ Karşılaştırmalı üstünlük yoktur.

2. Kategori $=1<\mathrm{AKÜ \leq}$; Zayıf bir karşılaştırmalı üstünlük vardır.

3. Kategori $=2<\mathrm{AKÜ} \leq 4$; Orta derecede karşılaştırmalı üstünlük vardır.

4. Kategori= $4<$ AKÜ ; Güçlü bir karşılaştırmalı üstünlük vardır.

Görüldüğü gibi ülkelerin rekabet gücü AKÜ endeksi yardımıyla dört aşamada sınıflandırılmaktadır. Bununla birlikte, AKÜ endeksinin eksikliklerini gidermeye yönelik olarak ülkelerin rekabet gücünü ölçebilecek yeni endeksler geliştirilmiştir.

Bunlardan bir tanesi ihracatta uzmanlaşma endeksidir. Ülkelerin sadece kendi ticaret performansını dikkate alan bu endeks alternatif bir AKÜ endeksi olarak geliştirilmiştir. Ülkenin veya ülke gruplarının bir mal veya endüstrideki eşanlı ihracat ve ithalat verilerini dikkate alan ihracatta uzmanlaşma endeksi şu şekilde formüle edilmektedir;

$E S=\frac{\left(X_{i j}-M_{i j}\right)}{\left(X_{i j}+M_{i j}\right)}$

Bu denklemde X (ihracat), M (ithalat), i (ülke), j (endüstri) olarak ifade edilmiş, endeks değerleri -1 ile +1 arasında değişmektedir. Endeksin 1'den büyük olması ülke veya ülke grubunun söz konusu mal grubundaki ihracatta avantajlı olduğunu ifade etmektedir (Greenway ve Miner, 1983: 181-208).

Rekabet gücünü analiz eden Volltarth (1991) tarafından üç alternatif yöntem önerilmektedir. Bu alternatif yöntemler, sırasıyla nisbi ticaret üstünlüğü (relative trade advantage-RTA), nisbi ihracat üstünlüğünün logaritmik formu (relative ${ }^{1}$ Rekabet gücü ve rekabet stratejisi hakkında detaylı bilgi için bkz. Aktan, C.C. ve Vural, Y.İ. (2004) “Rekabet Gücü ve Rekabet Stratejileri” Ankara,
TíSK Yayını Rekabet Dizisi: 3. 
export advantage-ln RXA) ve açıklanmış rekabet üstünlüğüdür (the revealed competitiveness-RC). Bu çalışmada söz konusu endeksler sırasıyla RC1 (AKÜ1), RC2 (AKÜ2) ve RC3 (AKÜ3) olarak adlandırılmıştır. Volltarth (1991)'ın önerdiği endekslerin pozitif değer alması ülkelerin söz konu mal grubundaki rekabet üstünlüğünü ifade ederken, negatif değer alması rekabet dezavantajını ifade etmektedir. Vollrath (1991)'ın AKÜ endeksinin Ballassa'nın orajinal endeksine yapmış olduğu katkı şu şekildedir. Vollrath (1991) hesaplamasında, AKÜ endeksinde iki kere hesaplamayı önleyebilmek amacıyla rekabet gücü karşılaştırılan ülkenin ticaret değerlerini, dahil olduğu o ülke grubu ticaretinden çıkarmıştır. Vollrath (1991) endeksini denklem örüntüsü aşağıdaki gibidir (Seymen, 2009);

RC1=RTA=RXA-RMA

$\mathrm{RXA}=\mathrm{RCA} 2=\frac{\left(X_{i j} / X_{i t}\right)}{\left(X_{n j}+X_{n t}\right)}$

$\mathrm{RMA}=\frac{\left(M_{i j} / M_{i t}\right)}{\left(M_{n j} / M_{n t}\right)}$

RXA ve RMA'yı açarak formüle eklediğimizde RC1'i elde etmek mümkün olacaktır:

$\mathrm{RC} 1=\mathrm{RTA}=\mathrm{RXA}-\mathrm{RMA}=\frac{\left(X_{i j} / X_{i t}\right)}{\left(X_{n j}+X_{n t}\right)}-\frac{\left(M_{i j} / M_{i t}\right)}{\left(M_{n j} / M_{n t}\right)}$

Vollrath (1991)'ın ikinci endeksi nisbi ihracat avantajı endeksinin logaritmik formundan oluşmaktadır (RC2)

$\mathrm{RC} 2=\ln \mathrm{RXA}=\ln \mathrm{RCA} 2$

Vollrath (1991) 'ın üçüncü endeksi ise açıklanmış rekabet avantajını (bu çalışmada RC3) vermektedir:

$\mathrm{RC} 3=\mathrm{RC}=\ln \mathrm{RXA}-\ln \mathrm{RMA}$

Vollrath (1991), bu endeksinin sadece arz değil talep koşullarını da dikkate aldığı için tercih edilmesi gerektiğini belirtmektedir. Endeks değerleri ise yine pozitif değerler rekabet avantajı koşullarını ifade ederken, negatif endeks değerleri rekabet dezavantajını ifade etmektedir.

\section{Literatür Taraması}

Literatürde rekabet gücü ölçümüne yönelik fazlaca çalışma söz konusudur. AKÜ ile ilgili yapılan çalışmaların bazıları şu şekildedir.

Şahin (2015), çalışmasında 1992-2013 yılları arası Türkiye'nin emek yoğun malların ihracatında karşılaştırmalı üstünlükleri analiz etmiş ve BRIC ülkeleri ile karşılaştırma yapılmıştır. Çalışmada elde edilen bulgulara göre, Türkiye, Çin ve Hindistan'ın faktör yoğunluğunun emek yoğun mallardan oluştuğu görülmüştür. Brezilya'nın faktör yoğunluğu sermaye yoğun mallar ve hammadde yoğun mallardan oluşmaktadır. Türkiye, Çin ve Hindistan'ın emek yoğun mallarda rekabet gücü yüksek bulunmuştur. Rusya'da emek yoğun malların rekabet gücünün düşük olduğu görülmüştür. Brezilya'da ise emek yoğun malların rekabet gücünün Rusya'ya göre yüksek ancak diğer ülkelere göre düşük olduğu görülmüştür.

Kara ve Erkan (2011), çalışmalarında, 1993-2009 yılları arasında Türkiye'nin emek yoğun mal ihracatındaki karşılaştırmalı üstünlükler ve söz konusu üstünlüklerin makro ekonomik değişkenlerle ilişkisini analiz etmişlerdir. Çalışmada elde edilen regresyon sonuçlarına göre, ihracat birim değer indeksi, işsizlik oranı, özel sektör kredileri, imalat sanayi yatırım teşvik belge sayısı, GSYH ve asgari ücretlerdeki değişikliklerin emek yoğun malların ihracat rekabet gücünü etkilediği ortaya çıkmaktadır.

Kösekahyaoğlu ve Özdamar (2011), Türkiye, Çin ve Hindistan'ın rekabet güçleri 1990-2009 dönemi dikkate alınarak Açıklanmış Karşılaştırmalı Üstünlük (AKÜ), İhracat Uzmanlık İndeksi (İUI) ve Karşılaştırmalı İhracat Performansı (KİP) İndeksi yardımıyla incelenmiştir. Çalışmada elde edilen bulgular; incelenen üç ülkenin rekabet gücünün beklendiği üzere temelde emek yoğun mallara dayandığına, ancak son dönemde Hindistan için özellikle sermaye yoğun malların öneminin daha da arttığına işaret etmektedir.

Utkulu ve Seymen (2004), 1990-2003 döneminde Türkiye'nin rekabet gücü farklı AKÜ indeksleri kullanılarak sektörel bazda incelenmiş ve gümrük birliği öncesi ve sonrası dönemler karşılaştırılmıştır. Kullanılan indekslerin tamamına göre Türkiye 7 sektörde rekabet gücüne sahipken 28 sektörde rekabet gücü söz konusu değildir. Gümrük birliği sonrasında 7 sektörde Türkiye'nin rekabet gücü zayıflamış, 3 sektörde ise artmıştır.

Altıntaş ve Akpolat (2013), Türkiye'nin AB-27 ülkeleri ile olan dış ticaretinde tekstil sektörünün rekabet gücü ölçülmüştür. 2004-2011 dönemi verileri kullanılarak Balassa, Vollrath ve KİP endeksleri ile rekabet düzeyi incelenmiş ve 2004-2011 döneminde Türkiye'nin AB-27 ülkelerine karsı karşılaştırmalı rekabet avantajına sahip olduğu ve 2011 yılına gelindiğinde söz konusu rekabet avantajının en yüksek düzeye ulaştığı sonucuna ulaşılmıştır. 
Çakmak (2015), Türkiye'nin tekstil ve hazır giyim sektörünün karşılaştırmalı üstünlük ve rekabetçiliğinin tüm alt sektörler itibariyle Balassa'nın Açıklanmış Karşılaştırmalı Üstünlükler İndeksi hesaplanmış ve daha sonra ise Vollrath'ın indeksi yardımıyla söz konusu endüstrilerin toplam mal grupları açısından rekabet gücünü araştırmıştır. Son yıllarda hemen hemen tüm ürün gruplarının rekabet gücünde önemli düşüşler olduğu görülmektedir. Dolayısıyla Türkiye'nin başta Avrupa Birliği olmak üzere Dünya piyasalarında sahip olduğu rekabet gücünü kaybetmemesi için, teknolojik gelişme ve AR-GE'ye önem vermesi ve verimlilik artışı sağlaması gerekmektedir.

Şahinli (2011), çalışmasında 2001-2009 yıllarına ilişkin veriler kullanılarak, Türkiye'nin ihracat oranlarının yüksek olduğu endüstriyel ürünler arasında yer alan pamuk ve pamuk ürünleri için yapmıştır. Bu amaç dahilinde, pamuk sektöründeki tüm alt ürün çeşitlerine ait Açıklanmış Karşılaştırmalı Üstünlükler Endeksi (AKÜ) hesaplanmıştır. Açıklanmış Karşılaştırmalı Üstünlükler Endeksine göre; Türkiye bazı pamuk ve pamuk ürünleri alt sektörlerinde karşılaştırmalı üstünlüğe sahip iken, bazı yıllarda karşılaştırmalı üstünlük söz konusu değildir.

Yalçınkaya vd. (2014), çalışmasında Çin ekonomisinin dünya ticaretindeki yerini belirlemek ve ticari ilişkileri kapsamında Türkiye ekonomisi üzerine etkilerini analiz etmektedir. Bu bağlamda, çalışmada Türkiye'nin Çin'e karşı rekabet gücü, ISIC Rev. 4 kapsamında sınıflandırılan Balassa'nın Açıklanmış Karşılaştırmalı Üstünlükler Endeksi kullanılarak belirlenmektedir. Elde edilen bulgulara göre, 2013 yılı sonu itibariyle metal cevheri madenciliği ile diğer madencilik ve taş ocakçılığı; gıda ürünleri ve içeceklerin imalatı; su temini, atık yönetimi ve iyileştirme aktiviteleri sanayinde atığın toplanması, ıslahı ve bertaraf faaliyetleri gibi 5 ürün grubunda karşılaştırmalı üstünlük tespit edilmiştir.

Bağcı (2016), 1995-2014 dönemleri arası verileri kullanarak, Türkiye'nin imalat sektörünün uluslararası rekabet gücünü tespit ve analizini yapmıştır. Çalışmada elde edilen bulgular; Türkiye'nin genel olarak imalat sanayi sektörü uluslararası rekabet gücüne sahip değildir. Ancak, Türkiye, ofis ve telekom araçları, makine - ulaşım araçları ve kimya sektöründe rekabet gücüne sahip değilken, yiyecek ve içecek, tekstil, giyim, demir ve çelik, otomotiv ürünleri sektöründe rekabet gücüne sahip olduğu tespit edilmiştir.

Pradumna (1988), 13 asya-pasifik ülkesinin 1965-1984 yılları arasındaki ihracat alanındaki rekabet gücünü ölçmüş söz konusu ülkelerin ağırlıklı olarak emek yoğun mallarda kısmi olarak da sermaye yoğun mallarda karşılaştırmalı üstünlüğe sahip oldukları bulgulanmıştır.

Granabetter (2016), Açıklanmış Karşılaştırmalı Üstünlükler Endeksi (AKÜ) kullanarak, Avusturya'nın Burgenland eyalatinin 2010-2014 yılları arasındaki ihratındaki rekabet gücünü ölçmüş, Burgenland eyaletinin hem Avusturya hem de Avrupa Birliği açısından önemli bir tarım merkezi olduğu tespit edilmiştir. Aynı zamanda bu eyalet, tarımsal ürünlerde karşılaştırma üstünlüğü sahiptir.

Fertö ve Hubbard (2003), AKÜ endeksi yardımıyla 1992-1998 dönemleri arasında Macaristan'ın işlenmiş tarım ve gıda üretiminin rekabet gücünü incelemişlerdir. Macaristan, hayvanlar ve et de dahil olmak üzere bir dizi tarımsal üründe karşılaştırmalı bir avantaja sahip olduğu gösterilmiştir.

Nath ve Goswami (2018), son yıllarda Hindistan'nın sadece dünyanın geri kalanıyla kıyaslandığında sadece hizmet ticaretinde önemli bir büyüme kaydetmediği aynı zamanda net bir hizmet ihracatçısı haline geldiğini ifade etmişlerdir. 2000'den 2013'e kadar toplam ayrıştırılmış hizmet kalemlerinin yıllık ihracat ve ithalat verilerini kullanan bu makale çeşitli karşılaştırmalı üstünlükler endekslerini hesaplar ve analiz eder. Analiz, Hindistan'ın tüm örneklem dönemi boyunca bilgisayar ve bilişim hizmetleri ile diğer iş hizmetlerinde (geniş bir bilgi yoğun hizmet yelpazesi içeren) bir karşılaştırmalı üstünlüğe sahip olmaya başladığını ortaya koyuyor

Balogh ve Jambor (2017), 2000-2013 dönemleri arası Avrupa Birliği içindeki 16 büyük şarap üreticisinin uluslararası rekabet gücünü Ballassa Endeksini kullanarak incelemişlerdir. Ayrıca, hesaplanan karşılaştırmalı üstünlüklere stabilite ve süre analizi uygulanmıştır. Sonuçlar, Bulgaristan, Kıbrıs, Fransa, Yunanistan, İtalya, Portekiz ve İspanya'nın dünya pazarında en yüksek derecedeki Avrupalı şarap üreticileri olduğunu ve en yüksek karşılaştırmalı üstünlüklere sahip olduğunu göstermektedir. Ancak, süre ve stabilite testleri bu ülkelerin çoğunda ticaret avantajlarının zayıfladığını göstermektedir. Çalışma aynı zamanda bu gerileme için Ortak Tarım Politikasının şarap düzenlemesi değişiklikleri, ekonomik kriz ve Yeni Dünya şarap üreticilerinin yükselişini de içeren bir takım nedenleri tartışmaktadır.

\section{Veri Seti ve Yöntem}

SITC teknoloji sınıflandırması (faktör yoğunluğu), ülkelerin ihraç ettiği mal kitlesini emek yoğun, sermaye yoğun, hammadde yoğun, kolay taklit edilen Ar-Ge bazlı ve zor taklit edilen Ar-Ge bazlı olmak üzere 5 kategori biçimine ayırmaktadır. Kısaca ülkelerin üretim ve ihracattaki faktör donatımı bu kategoriler çerçevesinde değerlendirilmesi söz konusudur. Tablo 1, SITC teknoloji sınıflandırması ve mal gruplarını göstermektedir. 
Çelik, A. / Journal of Yasar University, 2019, 14/55, 339-357

Tablo 1. SITC Teknoloji Sinıflandırması ve Mal Grupları

\begin{tabular}{|c|c|}
\hline \multicolumn{2}{|l|}{ Hammadde Yoğun Mallar } \\
\hline SITC 0 & Canlı Hayvanlar ve Gıda Maddeleri \\
\hline SITC 2(26 Hariç) & Tarımsal Hammaddeler \\
\hline SITC 3(35 Hariç) & Mineral Yakıtlar ve Mineral Yağlar \\
\hline SITC 4 & Hayvansal ve Bitkisel Yağlar \\
\hline SITC 56 & Gübre \\
\hline \multicolumn{2}{|l|}{ Emek Yoğun Mallar } \\
\hline SITC 26 & Dokumaya Elverişli Lifler (Elyaflar) \\
\hline SITC $6(62,67,68$ Hariç $)$ & İmalat Malları \\
\hline SITC 8 (87, 88 Hariç $)$ & Diğer Üretim Malları \\
\hline \multicolumn{2}{|l|}{ Sermaye Yoğun Mallar } \\
\hline SITC 1 & İçkiler, Tütün ve Mamülleri \\
\hline SITC 35 & Elektrik Enerjisi \\
\hline SITC 53 & Boyacılıkta Kullanılan Ürünler \\
\hline SITC 55 & Uçucu Yağlar, Rezinoitler, Parfümeri, Kozmetik \\
\hline SITC 62 & Kauçuk Eşya \\
\hline SITC 67 & Demir ve Çelik \\
\hline SITC 68 & Demir İhtiva Etmeyenler Madenler \\
\hline SITC 78 & Kara Taşıtları \\
\hline \multicolumn{2}{|c|}{ Kolay Taklit Edilen Ar-Ge Bazlı Mallar } \\
\hline SITC 51 & Organik Kimyasal Ürünler \\
\hline SITC 52 & İnorganik Kimyasal Ürünler \\
\hline SITC 54 & Tıp ve Eczacılık Ürünleri \\
\hline SITC 58 & İlk Haliyle Olmayan Plastikler \\
\hline SITC 59 & Kimyasal Maddeler ve Ürünler \\
\hline SITC 75 & Büro Makineleri, Otomotik Veri İşleme Makinesi \\
\hline SITC 76 & Haberleşme, Sesi Kaydetme ve Kaydedilen Sesi Tekrar Veren Alet \\
\hline \multicolumn{2}{|c|}{ Zor Taklit Edilen Ar-Ge Bazlı Mallar } \\
\hline SITC 57 & İlk Haliyle Plastik \\
\hline SITC 7 (75, 76, 78 Hariç) & Makineler ve Ulaşım Araçları \\
\hline SITC 87 & Mesleki, Bilimsel Ölçü ve Kontrol Cihazları \\
\hline SITC 88 & Fotoğraf Malzemeleri, Optik Eşyalar, Saatler \\
\hline
\end{tabular}


Kaynak: Comtrade veri tabanı kullanılarak tarafımızca hazırlanmıştır.

Bu çalışmada, 1995-2017 dönemleri arasında BRICS ve Türkiye'nin ihracat yapıları faktör yoğunlukları bakımından analiz edilmiştir. Rekabet gücünün analizinde AKÜ endeksinden (1 numaralı eşitlik) yararlanılmış ve veriler Birleşmiş Milletlerin (UN) Comtrade veri tabanından derlenmiştir. Ayrıca gerekli hesaplamalar SITC Rev. 3 iki haneli ürün grubu kapsamında hesaplamalar yapılmıştır.

\section{Bulgular ve Değerlendirmeler}

Ülkeler, faktör yoğunlukları ya da nispi faktör oranları bakımından farklılık gösterir. İhracatı ya da ithalatı yapılan malların faktör yoğunlukları ülkelerin diş ticaret performansının belirlenmesinde, rekabet avantajı ve dezavantajı sağlanan üretim kollarının keşfedilmesinde, dış ticaret hacmi ve yapısının değerlendirilmesinde son derecede önemlidir. Bu bağlamda, ülkelerin makro ekonomik göstergelerinin birçoğunu olumlu düzeyde etkileyen ihracat performansının faktör yoğunlukları bakımından yukarıdaki teorik çerçeve zemininde ampirik kanıtları sunulmuştur.

Tablo 2’de BRICS ve Türkiye'nin Emek Yoğun Mal İhracının Toplam İhracat İçindeki Payı (\%)

\begin{tabular}{|l|l|l|l|l|l|l|}
\hline Yıllar/Ülkeler & Brezilya & Rusya & Hindistan & Çin & G..Afrika & Türkiye \\
\hline $\mathbf{1 9 9 5}$ & 16.3 & 4.1 & 53.6 & 57.2 & 38.5 & 49.5 \\
\hline $\mathbf{1 9 9 6}$ & 15.7 & 3.9 & 51.9 & 48.6 & 34.5 & 48.7 \\
\hline $\mathbf{1 9 9 7}$ & 16.7 & 3.9 & 52.1 & 49.3 & 37.8 & 49.2 \\
\hline $\mathbf{1 9 9 8}$ & 13.4 & 6.9 & 56.1 & 48.3 & 26.8 & 50.4 \\
\hline $\mathbf{1 9 9 9}$ & 13.7 & 6.5 & 58.3 & 47.5 & 23.4 & 48.9 \\
\hline $\mathbf{2 0 0 0}$ & 16.7 & 5.2 & 55.9 & 44.7 & 17.1 & 48.7 \\
\hline $\mathbf{2 0 0 1}$ & 14.2 & 5.1 & 51.4 & 42.9 & 16.1 & 45.7 \\
\hline $\mathbf{2 0 0 2}$ & 13.7 & 4.6 & 49.1 & 41.5 & 18.2 & 46.6 \\
\hline $\mathbf{2 0 0 3}$ & 13.7 & 3.9 & 49.8 & 38.4 & 15.8 & 45.5 \\
\hline $\mathbf{2 0 0 4}$ & 13.3 & 3.6 & 45.4 & 35.3 & 14.1 & 41.1 \\
\hline $\mathbf{2 0 0 5}$ & 11.6 & 3.1 & 42.4 & 34.3 & 13.2 & 39.1 \\
\hline $\mathbf{2 0 0 6}$ & 10.8 & 2.9 & 37.5 & 33.2 & 11.7 & 39.1 \\
\hline $\mathbf{2 0 0 7}$ & 10.1 & 2.9 & 35.7 & 31.9 & 10.8 & 34.5 \\
\hline $\mathbf{2 0 0 8}$ & 8.4 & 2.2 & 31.3 & 30.3 & 9.2 & 30.6 \\
\hline $\mathbf{2 0 0 9}$ & 8.5 & 2.6 & 36.6 & 31.9 & 8.9 & 33.2 \\
\hline $\mathbf{2 0 1 0}$ & 7.5 & 2.2 & 33.1 & 31.4 & 11.1 & 33.9 \\
\hline $\mathbf{2 0 1 1}$ & 6.6 & 2.1 & 33.5 & 30.9 & 8.8 & 32.9 \\
\hline $\mathbf{2 0 1 2}$ & 7.1 & 3.1 & 32.9 & 32.2 & 9.4 & 30.8 \\
\hline $\mathbf{2 0 1 3}$ & 6.8 & 3.4 & 31.1 & 32.5 & 9.3 & 34.1 \\
\hline $\mathbf{2 0 1 4}$ & 7.6 & 3.8 & 31.7 & 33.6 & 9.9 & 35.3 \\
\hline $\mathbf{2 0 1 5}$ & 8.5 & 4.6 & 35.1 & 33.7 & 9.7 & 34.5 \\
\hline $\mathbf{2 0 1 6}$ & 8.5 & 4.8 & 36.8 & 32.6 & 10.3 & 34.3 \\
\hline $\mathbf{2 0 1 7}$ & 7.5 & 4.6 & 33.6 & 30.8 & 9.2 & 32.7 \\
\hline
\end{tabular}

Kaynak: Comtrade verilerinden yararlanılmıştır.

Tablo 2'de, söz konusu ülkelerin emek yoğun sektörlerinin toplam ihracat içindeki payı incelenmiştir. Buna göre, 1995 yılında Brezilya'nın ihraç ettiği malların \%16.3'ü, Rusya'nın ihraç ettiği malların \%4.1'i, Hindistan'nın ihraç ettiği malların \%53.6'sı, Çin'nin ihraç ettiği malların \%57.2'si, G.Afrika'nın ihraç ettiği malların \%38.5'i, Türkiye'nin ihraç ettiği malların \%49.5'i emek yoğun mallardan oluşmaktadır. 2017 yılına gelindiğinde, Brezilya'nın ihraç ettiği malların \%7.5'i, Rusya'nın ihraç ettiği malların \%4.6'sı, Hindistan'nın ihraç ettiği malların \%33.6'sı, Çin'nin ihraç ettiği malların \%30.8'si, G.Afrika'nın ihraç ettiği malların \%9.2'si, Türkiye'nin ihraç ettiği malların \%32.7'si emek yoğun mallardan oluşmaktadır. Bu bulgara toplu şekilde bakıldığında, özellikle Çin, Hindistan ve Türkiye gibi ülkelerin katma değeri düşük mallard söz sahibi olduğunu yani katma değeri yüksek malları ithal etme durumunda kaldığı ve dış ticaret hadlerine de aleyhte bir etki yapabileceği tespit edilmiştir. Türkiye gibi yükselen piyasa ekonomisi klasmanında olan bir ülkenin 
özellikle katma değeri yüksek ürünlerde uzmanlaşmayı sağlamalı ve bu üretim alanlarını geliştirecek stratejiler geliştirmelidir. Ülke ekonomisinin gelişimi ve kalkınması açısında bu tür girişimler ve uygulamalar hayati önem olduğu belirtilmelidir.

Tablo 3. BRICS ve Türkiye’nin Sermaye Yoğun Mal İhracının Toplam İhracat İçindeki Payı (\%)

\begin{tabular}{|c|c|c|c|c|c|c|}
\hline Yıllar/Ülkeler & Brezilya & Rusya & Hindistan & Çin & G..Afrika & Türkiye \\
\hline 1995 & 23.7 & 33.2 & 8.8 & 10.1 & - & 18.5 \\
\hline 1996 & 23.9 & 32.2 & 9.0 & 7.3 & - & 19.4 \\
\hline 1997 & 27.8 & 34.3 & 9.5 & 7.2 & - & 18.3 \\
\hline 1998 & 23.6 & 39.3 & 7.5 & 7.0 & - & 16.7 \\
\hline 1999 & 20.0 & 31.3 & 7.9 & 6.6 & - & 18.1 \\
\hline 2000 & 24.6 & 26.8 & 8.3 & 7.4 & 25.1 & 18.0 \\
\hline 2001 & 18.7 & 24.9 & 7.7 & 6.6 & 36.9 & 20.7 \\
\hline 2002 & 19.5 & 25.2 & 8.7 & 6.1 & 29.9 & 21.4 \\
\hline 2003 & 20.5 & 24.9 & 10.4 & 6.3 & 40.2 & 22.2 \\
\hline 2004 & 21.2 & 27.1 & 11.7 & 7.9 & 43.7 & 27.1 \\
\hline 2005 & 22.3 & 24.6 & 12.0 & 8.1 & 40.0 & 25.7 \\
\hline 2006 & 21.5 & 24.0 & 13.3 & 9.3 & 43.3 & 25.7 \\
\hline 2007 & 20.1 & 23.7 & 12.7 & 10.2 & 43.1 & 28.7 \\
\hline 2008 & 19.1 & 19.6 & 13.2 & 10.5 & 42.2 & 31.2 \\
\hline 2009 & 16.2 & \begin{tabular}{|l|}
19.6 \\
\end{tabular} & 10.8 & 6.7 & 39.0 & 25.8 \\
\hline 2010 & 14.7 & 17.7 & 13.9 & 7.9 & 37.9 & 26.8 \\
\hline 2011 & 14.2 & \begin{tabular}{|l|}
15.7 \\
\end{tabular} & 9.8 & 8.5 & 31.8 & 27.1 \\
\hline 2012 & 13.6 & 16.0 & 11.2 & 7.9 & 30.0 & 23.7 \\
\hline 2013 & 13.2 & 15.0 & \begin{tabular}{|l|}
11.1 \\
\end{tabular} & 7.6 & 30.9 & 24.2 \\
\hline 2014 & 12.5 & 14.7 & 11.9 & 8.5 & 31.3 & 23.7 \\
\hline 2015 & 13.9 & 18.7 & 12.4 & 8.2 & 34.2 & 22.8 \\
\hline 2016 & 14.1 & 19.8 & 12.6 & 7.9 & 35.4 & 24.1 \\
\hline 2017 & 15.1 & 21.7 & 14.6 & 7.9 & 32.8 & 26.6 \\
\hline
\end{tabular}

Kaynak: Comtrade veri tabanı kullanılarak tarafımızca hazırlanmıştır.

Tablo 3'deki BRICS ve Türkiye ekonomilerinin sermaye yoğun sektörlerinin toplam ihracat içindeki payına bakıldığında, 1995 yılında Brezilya'nın ihraç ettiği malların \%23.7'si, Rusya'nın ihraç ettiği malların \%33.2'si, Hindistan'nın ihraç ettiği malların \%8.8'i, Çin'nin ihraç ettiği malların \%10.1'i, Türkiye'nin ihraç ettiği malların \%18.5'i sermaye yoğun mallardan oluşmaktadır. 2017 yılına gelindiğinde, Brezilya'nın ihraç ettiği malların \%15.1'i, Rusya'nın ihraç ettiği malların \%21.7'si, Hindistan'nın ihraç ettiği malların \%14.6'sı, Çin'nin ihraç ettiği malların \%7.9'u, G.Afrika'nın ihraç ettiği malların \%32.8'i ve Türkiye'nin ihraç ettiği malların \%26.6'si sermaye yoğun mallardan oluşmaktadır. Bir önceki tablo ile kıyaslandığında Türkiye ekonomisinin emek yoğun ve sermaye yoğun mal kategorilerinde toplam ihracat için önemli bir yer işgal ettiği gözlenmiştir. BRICS ülke grubunun dominosu olan Çin ise sermaye yoğun mal grubunda toplam ihracat payı içindeki payı görece düşük seviyede olduğu tespit edilmiştir.

Tablo 4. BRICS ve Türkiye'nin Hammadde Yoğun Mal İhracının Toplam İhracat İçindeki Payı (\%)

\begin{tabular}{|l|l|l|l|l|l|l|}
\hline Yıllar/Ülkeler & Brezilya & Rusya & Hindistan & Çin & G..Afrika & Türkiye \\
\hline $\mathbf{1 9 9 5}$ & 37.8 & 51.2 & 24.0 & 14.5 & - & 21.7 \\
\hline $\mathbf{1 9 9 6}$ & 37.7 & 51.3 & 23.6 & 12.8 & - & 19.4 \\
\hline $\mathbf{1 9 9 7}$ & 43.9 & 55.1 & 21.6 & 11.6 & - & 19.0 \\
\hline $\mathbf{1 9 9 8}$ & 37.0 & 49.2 & 20.5 & 9.9 & - & 17.4 \\
\hline $\mathbf{1 9 9 9}$ & 36.6 & 51.4 & 17.2 & 9.0 & - & 16.5 \\
\hline $\mathbf{2 0 0 0}$ & 40.0 & 57.5 & 18.6 & 9.2 & 26.6 & 13.3 \\
\hline
\end{tabular}




\begin{tabular}{|l|l|l|l|l|l|l|}
$\mathbf{2 0 0 1}$ & 39.5 & 58.7 & 21.0 & 9.0 & 28.1 & 14.0 \\
\hline $\mathbf{2 0 0 2}$ & 40.9 & 60.0 & 20.3 & 7.9 & 30.7 & 12.2 \\
\hline $\mathbf{2 0 0 3}$ & 42.5 & 61.8 & 20.2 & 7.3 & 25.9 & 12.5 \\
\hline $\mathbf{2 0 0 4}$ & 41.1 & 61.9 & 23.3 & 6.4 & 23.3 & 12.0 \\
\hline $\mathbf{2 0 0 5}$ & 41.5 & 68.9 & 25.8 & 6.1 & 25.6 & 14.4 \\
\hline $\mathbf{2 0 0 6}$ & 43.4 & 69.2 & 28.7 & 5.1 & 25.3 & 14.4 \\
\hline $\mathbf{2 0 0 7}$ & 45.5 & 69.1 & 30.7 & 4.9 & 26.4 & 14.4 \\
\hline $\mathbf{2 0 0 8}$ & 49.5 & 73.1 & 32.9 & 5.2 & 29.6 & 15.1 \\
\hline $\mathbf{2 0 0 9}$ & 54.2 & 70.4 & 25.6 & 4.9 & 34.3 & 15.1 \\
\hline $\mathbf{2 0 1 0}$ & 58.6 & 72.1 & 29.9 & 5.1 & 34.1 & 16.2 \\
\hline $\mathbf{2 0 1 1}$ & 61.0 & 74.1 & 30.9 & 5.0 & 34.0 & 17.0 \\
\hline $\mathbf{2 0 1 2}$ & 59.3 & 78.3 & 33.4 & 4.6 & 34.8 & 16.4 \\
\hline $\mathbf{2 0 1 3}$ & 58.8 & 77.9 & 34.1 & 4.5 & 36.3 & 17.5 \\
\hline $\mathbf{2 0 1 4}$ & 60.7 & 77.8 & 32.9 & 4.6 & 34.5 & 16.8 \\
\hline $\mathbf{2 0 1 5}$ & 57.9 & 72.9 & 24.7 & 4.5 & 32.0 & 15.9 \\
\hline $\mathbf{2 0 1 6}$ & 56.2 & 65.9 & 23.4 & 4.7 & 32.0 & 14.7 \\
\hline $\mathbf{2 0 1 7}$ & 59.3 & 72.3 & 25.6 & 4.8 & 36.4 & 15.0 \\
\hline
\end{tabular}

Kaynak: Comtrade veri tabanı kullanılarak tarafimızca hazırlanmışıtır.

Tablo 4'deki BRICS ve Türkiye ekonomilerinin hammadde yoğun sektörlerinin toplam ihracat içindeki payına bakıldı̆̆ında, 1995 yılında Brezilya'nın ihraç ettiği malların \%37.8'i, Rusya'nın ihraç ettiği malların \%51.2'si, Hindistan'nın ihraç ettiği malların \%24'ü, Çin'nin ihraç ettiği malların \%14.5'i, Türkiye'nin ihraç ettiği malların \%21.5'i hammadde yoğun mallardan oluşmaktadır. 2017 yılına gelindiğinde, Brezilya'nın ihraç ettiği malların \%59.3'ü, Rusya'nın ihraç ettiği malların \%72.3'ü, Hindistan'nın ihraç ettiği malların \%25.6'sı, Çin'nin ihraç ettiği malların \%4.8'i, G.Afrika'nın ihraç ettiği malların \%32.8'i ve Türkiye'nin ihraç ettiği malların \%26.6'si hammadde yoğun mallardan oluşmaktadır. Hammadde yoğun mal üretimi daha çok ülkelerin üzerinde yaşanılan coğrafyaya koşut olarak doğal koşulların sağlamış olduğu koşullar sayesinde üretilen ve dış ticarete konu olan bu mal kategorileri ülkeler için ürerim açısından avantajları veya dezavantajlı durumlar ortaya çıkarmaktadır. Söz konusu ülkeler bakımından bu doğal avantajla sahip olan en önemli ülkeler, toplam ihracatlarının içinde hammadde yoğun mal ihracının payı \%50'nin üzerinde olan Brezilya ve Rusya olduğu gözlenmiştir.

Tablo 5. BRICS ve Türkiye'nin Kolay Taklit Edilebilir Ar-Ge Bazlı Mal İhracının Toplam İhracat İçindeki Payı (\%)

\begin{tabular}{|l|l|l|l|l|l|l|}
\hline Yllar/Ülkeler & Brezilya & Rusya & Hindistan & Çin & G.Afrika & Türkiye \\
\hline $\mathbf{1 9 9 5}$ & 5.8 & 3.6 & 7.3 & 15.5 & - & 3.2 \\
\hline $\mathbf{1 9 9 6}$ & 6.3 & 3.7 & 8.1 & 14.8 & - & 3.0 \\
\hline $\mathbf{1 9 9 7}$ & 7.2 & 3.5 & 8.6 & 14.8 & - & 3.8 \\
\hline $\mathbf{1 9 9 8}$ & 6.0 & 3.2 & 7.8 & 16.5 & - & 4.8 \\
\hline $\mathbf{1 9 9 9}$ & 6.5 & 3.0 & 8.4 & 17.5 & - & 5.6 \\
\hline $\mathbf{2 0 0 0}$ & 9.4 & 3.9 & 8.5 & 18.8 & 7.2 & 5.8 \\
\hline $\mathbf{2 0 0 1}$ & 7.5 & 2.7 & 9.3 & 21.3 & 6.9 & 5.7 \\
\hline $\mathbf{2 0 0 2}$ & 7.5 & 2.5 & 8.9 & 24.1 & 7.8 & 6.4 \\
\hline $\mathbf{2 0 0 3}$ & 6.7 & 2.5 & 9.6 & 27.4 & 6.6 & 6.1 \\
\hline $\mathbf{2 0 0 4}$ & 5.9 & 2.6 & 9.5 & 29.0 & 6.9 & 6.6 \\
\hline $\mathbf{2 0 0 5}$ & 7.1 & 2.4 & 9.5 & 30.2 & 7.1 & 6.5 \\
\hline $\mathbf{2 0 0 6}$ & 7.3 & 2.4 & 9.7 & 29.5 & 6.7 & 6.6 \\
\hline $\mathbf{2 0 0 7}$ & 6.1 & 2.3 & 9.6 & 28.4 & 6.3 & 5.0 \\
\hline $\mathbf{2 0 0 8}$ & 6.1 & 2.1 & 9.8 & 26.8 & 6.5 & 4.2 \\
\hline $\mathbf{2 0 0 9}$ & 6.1 & 2.1 & 11.4 & 28.4 & 6.1 & 4.6 \\
\hline
\end{tabular}




\begin{tabular}{|l|l|l|l|l|l|l|}
$\mathbf{2 0 1 0}$ & 5.1 & 2.0 & 9.9 & 28.3 & 5.8 & 4.8 \\
\hline $\mathbf{2 0 1 1}$ & 4.6 & 2.2 & 10.1 & 25.6 & 5.3 & 4.7 \\
\hline $\mathbf{2 0 1 2}$ & 4.8 & 2.4 & 11.4 & 24.9 & 6.0 & 4.8 \\
\hline $\mathbf{2 0 1 3}$ & 4.6 & 2.6 & 10.7 & 24.0 & 5.6 & 4.8 \\
\hline $\mathbf{2 0 1 4}$ & 4.3 & 3.1 & 10.1 & 24.4 & 6.2 & 4.9 \\
\hline $\mathbf{2 0 1 5}$ & 4.2 & 3.3 & 11.8 & 24.5 & 6.1 & 4.9 \\
\hline $\mathbf{2 0 1 6}$ & 4.0 & 2.7 & 12.2 & 24.7 & 5.8 & 4.6 \\
\hline $\mathbf{2 0 1 7}$ & 3.9 & 2.8 & 11.8 & 25.0 & 5.5 & 4.4 \\
\hline
\end{tabular}

Kaynak: Comtrade veri tabanı kullanılarak tarafimızca hazırlanmıştır.

Tablo 5'deki BRICS ve Türkiye ekonomilerinin kolay taklit edilen Ar-Ge bazlı mal ihracının toplam ihracat içindeki payına bakıldığında, 1995 yılında Brezilya'nın ihraç ettiği malların \%5.8'i, Rusya'nın ihraç ettiği malların \%3.6'si, Hindistan'nın ihraç ettiği malların \%7.3'ü, Çin'nin ihraç ettiği malların \%15.5'i, Türkiye'nin ihraç ettiği malların \%3.2'si kolay taklit edilen Ar-Ge bazlı mallardan oluşmaktadır. 2017 yılına gelindiğinde, Brezilya'nın ihraç ettiği malların \%3.9'u, Rusya'nın ihraç ettiği malların \%2.8'ü, Hindistan'nın ihraç ettiği malların \%11.8'i, Çin'nin ihraç ettiği malların \%25.0'1, G.Afrika'nın ihraç ettiği malların \%5.5'i ve Türkiye'nin ihraç ettiği malların \%4.4'ü kolay taklit edilen Ar-Ge bazlı mallardan oluşmaktadır. Ar-Ge bazlı üretim, katma değeri yüksek mal üretimini amaçlayanlar için yaşamsal önem sahiptir. BRICS ülkelerinden Çin'in her geçen yıl katma değeri yüksek Ar-Ge bazlı mal ihracının toplam ihracat içindeki payındaki artışı son derece dikkat çekicidir. Çin'i, Hindistan takip etmektedir. Hindistan ekonomisi için de kolay taklit edilebilir Ar-Ge bazlı mal ihracatında görece iyileşmeler tespit edilmiş̧ir. Bu durum, genellikle emek yoğun, niteliksiz ve katma değeri düşük mal ihracında rekabet avantajına sahibi olan ülkelerin, üretim stratejisini değiştirdiğine dair önemli emareler sunmaktadır. Türkiye özelinde bakıldığında, Türkiye ekonomisinin de aynı ölçekte ülkeler olmamasına rağmen Çin ve Hindistan ekonomilerine benzer bir ekonomi politikası izlemesi gerektiği gözler önüne serilmektedir.

Tablo 6. BRICS ve Türkiye’nin Zor Taklit Edilebilir Ar-Ge Bazlı Mal İhracının Toplam İhracat İçindeki Payı (\%)

\begin{tabular}{|l|l|l|l|l|l|l|}
\hline Yllar/Ülkeler & Brezilya & Rusya & Hindistan & Çin & G..Afrika & Türkiye \\
\hline $\mathbf{1 9 9 5}$ & 14.0 & 5.9 & 4.1 & 15.2 & - & 7.4 \\
\hline $\mathbf{1 9 9 6}$ & 14.0 & 5.9 & 5.1 & 14.0 & - & 8.2 \\
\hline $\mathbf{1 9 9 7}$ & 16.5 & 4.5 & 5.5 & 14.4 & - & 8.8 \\
\hline $\mathbf{1 9 9 8}$ & 14.7 & 7.6 & 5.4 & 15.7 & - & 9.3 \\
\hline $\mathbf{1 9 9 9}$ & 15.1 & 7.3 & 5.4 & 17.4 & - & 10.9 \\
\hline $\mathbf{2 0 0 0}$ & 21.0 & 6.4 & 5.9 & 18.1 & 10.3 & 11.9 \\
\hline $\mathbf{2 0 0 1}$ & 17.3 & 6.9 & 7.1 & 17.8 & 11.5 & 12.8 \\
\hline $\mathbf{2 0 0 2}$ & 15.7 & 7.2 & 6.9 & 17.9 & 12.1 & 11.1 \\
\hline $\mathbf{2 0 0 3}$ & 14.5 & 6.5 & 7.6 & 18.2 & 10.8 & 12.1 \\
\hline $\mathbf{2 0 0 4}$ & 16.7 & 5.3 & 8.4 & 19.0 & 10.9 & 12.0 \\
\hline $\mathbf{2 0 0 5}$ & 15.3 & 3.5 & 8.7 & 19.6 & 11.5 & 12.7 \\
\hline $\mathbf{2 0 0 6}$ & 14.7 & 3.1 & 9.2 & 20.5 & 12.5 & 12.6 \\
\hline $\mathbf{2 0 0 7}$ & 15.1 & 3.1 & 9.5 & 21.6 & 12.8 & 15.4 \\
\hline $\mathbf{2 0 0 8}$ & 13.9 & 2.9 & 11.2 & 22.8 & 12.2 & 15.0 \\
\hline $\mathbf{2 0 0 9}$ & 12.2 & 3.3 & 10.6 & 24.1 & 11.1 & 15.5 \\
\hline $\mathbf{2 0 1 0}$ & 11.3 & 2.7 & 10.5 & 25.7 & 10.8 & 15.2 \\
\hline $\mathbf{2 0 1 1}$ & 10.8 & 2.1 & 10.3 & 24.4 & 10.0 & 15.6 \\
\hline $\mathbf{2 0 1 2}$ & 11.7 & 3.2 & 9.5 & 24.5 & 10.7 & 14.2 \\
\hline $\mathbf{2 0 1 3}$ & 13.5 & 3.5 & 10.1 & 25.0 & 10.5 & 15.8 \\
\hline $\mathbf{2 0 1 4}$ & 11.6 & 3.3 & 11.8 & 23.9 & 11.0 & 15.7 \\
\hline $\mathbf{2 0 1 5}$ & 12.8 & 4.6 & 12.4 & 25.2 & 11.2 & 15.2 \\
\hline $\mathbf{2 0 1 6}$ & 14.5 & 4.1 & 12.3 & 25.2 & 10.9 & 15.1 \\
\hline $\mathbf{2 0 1 7}$ & 14.2 & 4.0 & 14.4 & 21.5 & 16.1 & 17.3 \\
\hline & & & & & & \\
\hline
\end{tabular}




\section{Kaynak: Comtrade veri tabanı kullanılarak tarafımızca hazırlanmıştır.}

Tablo 6'daki BRICS ve Türkiye ekonomilerinin zor taklit edilen Ar-Ge bazlı mal ihracının toplam ihracat içindeki payına bakıldığında, 1995 yılında Brezilya'nın ihraç ettiği malların \%14.0'1, Rusya'nın ihraç ettiği malların \%5.9'u, Hindistan'nın ihraç ettiği malların \%4.1'i, Çin'nin ihraç ettiği malların \%15.2'i, Türkiye'nin ihraç ettiği malların \%7.2'si zor taklit edilen Ar-Ge bazlı mallardan oluşmaktadır. 2017 yılına gelindiğinde, Brezilya'nın ihraç ettiği malların \%3.9’u, Rusya'nın ihraç ettiği malların \%2.8'ü, Hindistan'nın ihraç ettiği malların \%11.8'i, Çin'nin ihraç ettiği malların \%25.0'1, G.Afrika'nın ihraç ettiği malların \%5.5'i ve Türkiye'nin ihraç ettiği malların \%4.4'ü zor taklit edilen Ar-Ge bazlı mallardan oluşmaktadır. Katma değerli üretim yapmak isteyen kesimler açısından Ar-Ge bazlı üretim ve ihracatın önemi üzerinde yukarıda durduk. Söz konusu ülkeler açısından zor taklit edilebilen Ar-Ge bazlı mal ihracatlarının, toplam ihracat içindeki paylarına bakıldığında kolay taklit edilebilen Ar-Ge bazlı mal ihracatlarına gore daha iyimser bir resmin olduğu söylenebilir. Ancak bu ülkeler arasında Çin ekonomisi yine katma değeri yüksek olan zor taklit edilebilen Ar-Ge bazlı üretim ve ihracatta göreli bir artış seyri izlemektedir. Türkiye ekonomisi de söz konusu mal kategolerinin yani katma değeri yüksek mal kategorilerinin üretim ve ihracatını giderek arttırdığı tespit edilmiştir.

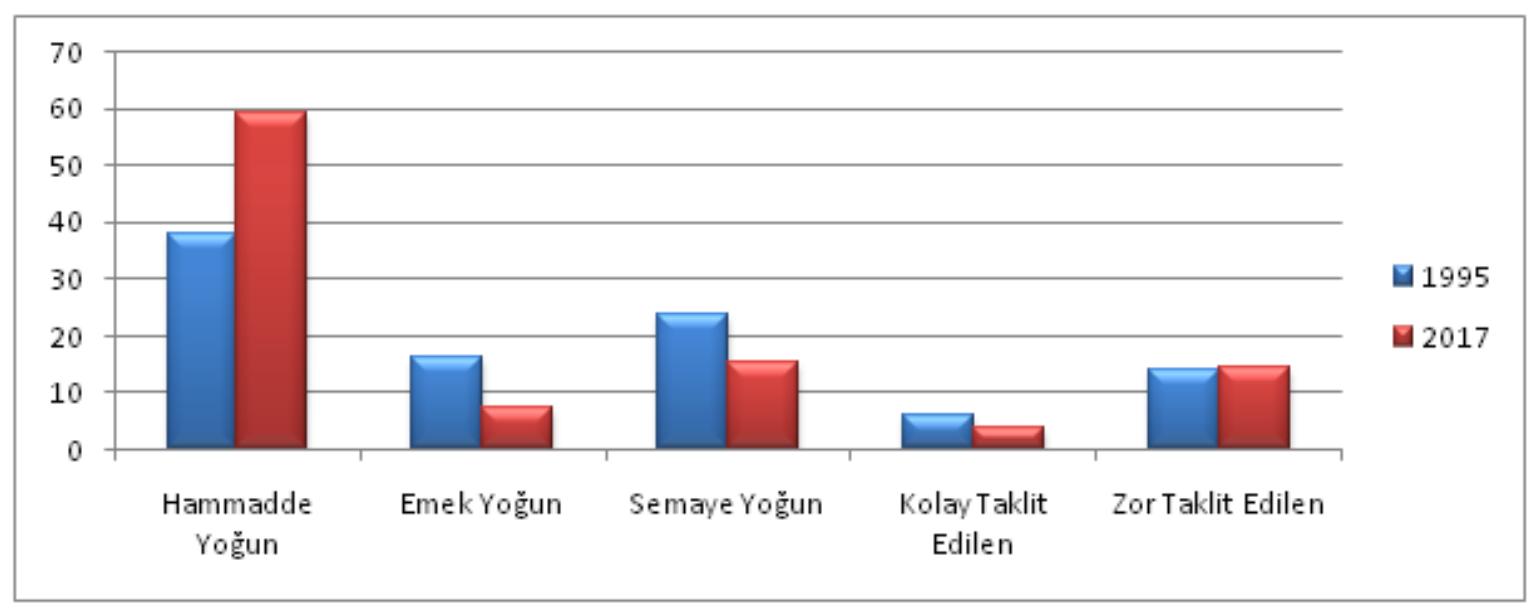

Grafik 1. Brezilya’nın Faktör Donatımına Göre İhracat Payı (\%) (1995,2017) SITC Mal Grupları

Kaynak: Comtrade veri tabanı kullanılarak tarafımızca hazırlanmıştır.

Grafik 1'deki Brezilya ekonomisinin üretim ve ihracatındaki faktör donatımı incelendiğinde, hammadde yoğun malların toplam ihracat içinde görece baskın olduğu tespit edilmiştir. 1995 yılında toplam ihracatının \%37.8 civarında hammadde yoğun üretim gerçekleştiren Brezilya ekonomisi, 2017 yılında bu rakamı \%58.8'e kadar yükselttiği gözlenmiştir. Bununla birlikte, hammadde yoğun sektörlerdeki gelişme ve uzmanlaşma üretimin ve toplam ihracatın emek yoğun ve sermaye yoğun payını düşürdüğü tespit edilmiştir.

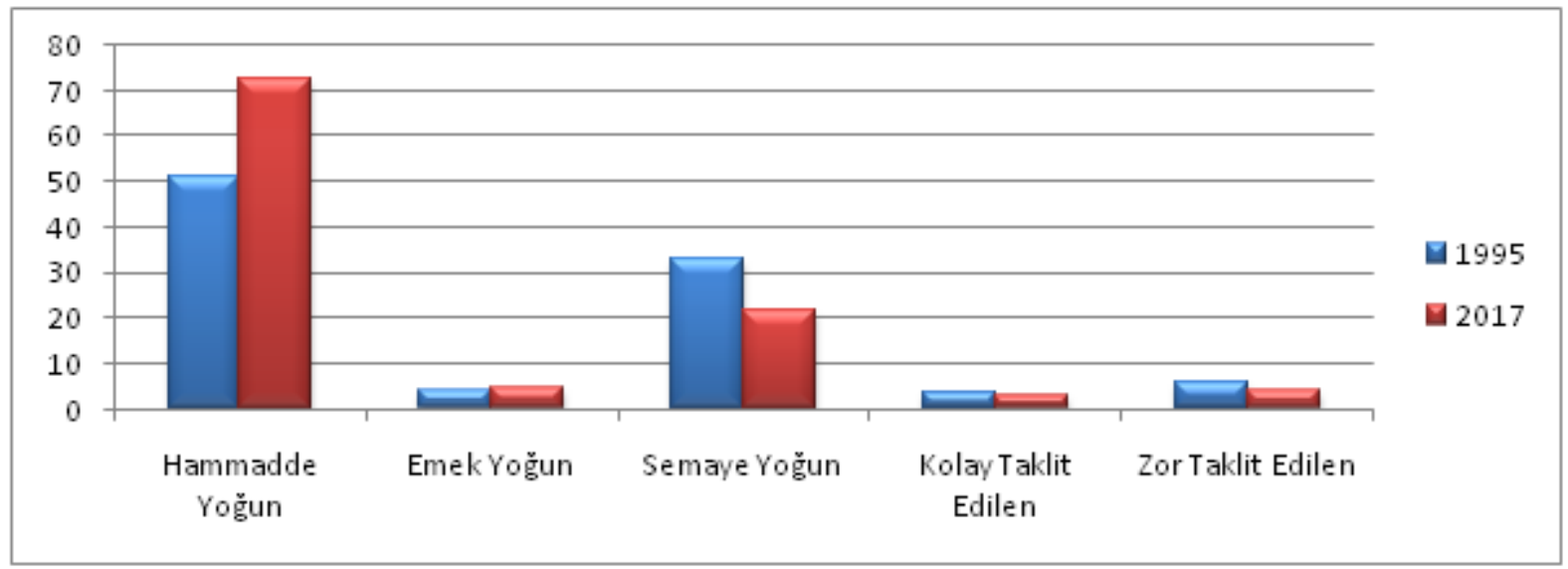

Grafik 2. Rusya'nın Faktör Donatımına Göre İhracat Payı (\%) (1995,2017) SITC Mal Grupları Kaynak: Comtrade veri tabanı kullanılarak tarafimızca hazırlanmıştır. 
Grafik 2'de Rusya ekonomisinin üretim ve ihracatındaki faktör donatımı incelendiğinde, hammadde yoğun malların toplam ihracat içinde ağırlık teşkil ettiği söylenebilir. 1995 yılında toplam ihracatının \%51.2 civarında hammadde yoğun üretim gerçekleştiren Rusya ekonomisi, 2017 yılında bu rakamı \%72'lere kadar yükselttiği gözlenmiştir. Aynı zamanda, Rusya ekonomisinin toplam ihracatı içinde sermaye yoğun mal gruplarının üretiminde ve ihracatında azalma meydana gelmiştir.

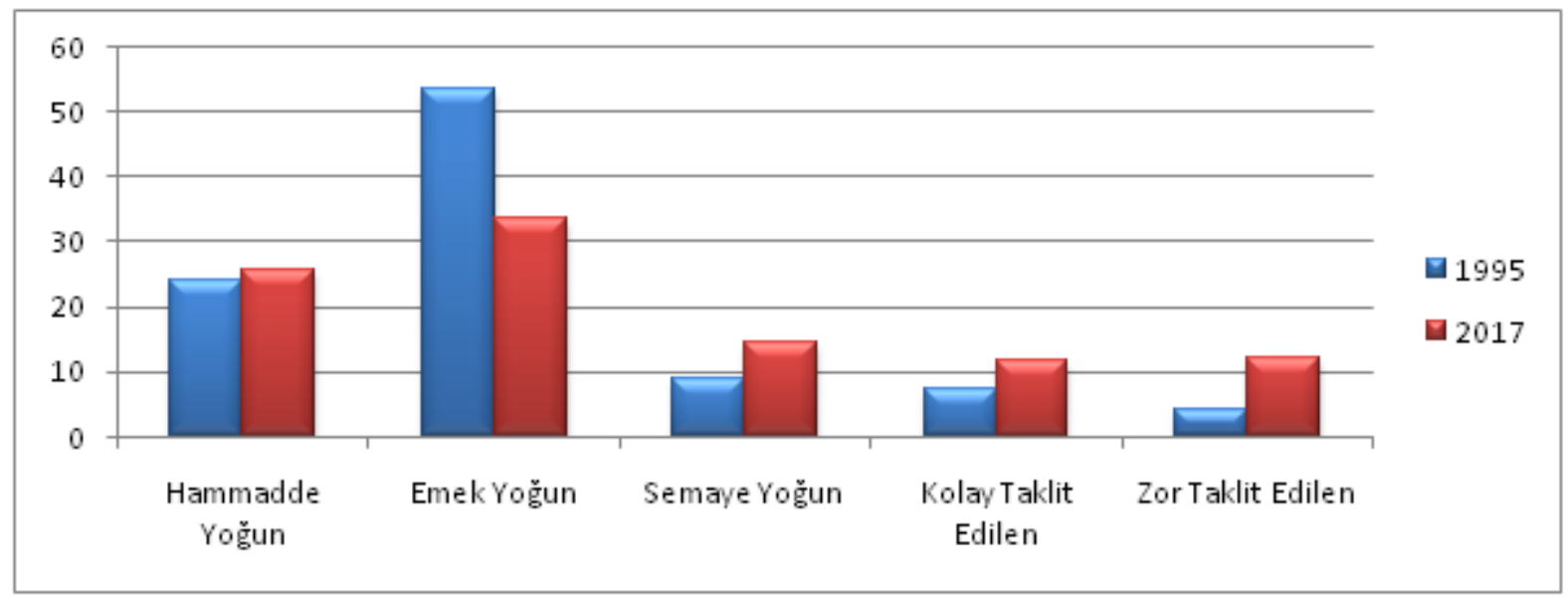

Grafik 3. Hindistan'nın Faktör Donatımına Göre İhracat Payı (\%) (1995,2017) SITC Mal Grupları

Kaynak: Comtrade veri tabanı kullanılarak tarafımızca hazırlanmıştır.

Grafik 3'de Hindistan ekonomisinin üretim ve ihracatındaki faktör donatımı incelendiğinde, emek yoğun malların toplam ihracat içinde ağırlık teşkil ettiği söylenebilir. 1995 yılında Hindistan'nın toplam ihracatının \%53.6'sı emek yoğun malların üretiminden oluşurken, 2017 yılında bu rakamın \%33'lara kadar gerilediği gözlenmiştir. Aynı zamanda, diğer teknolojik sınıflandırılması kategorilerinde göreceli artışlar meydana gelmiştir. Ancak emek yoğun sektörlerin Hindistan ekonomisi içerisinde çok önemli bir payı olduğu gözlenmiştir.

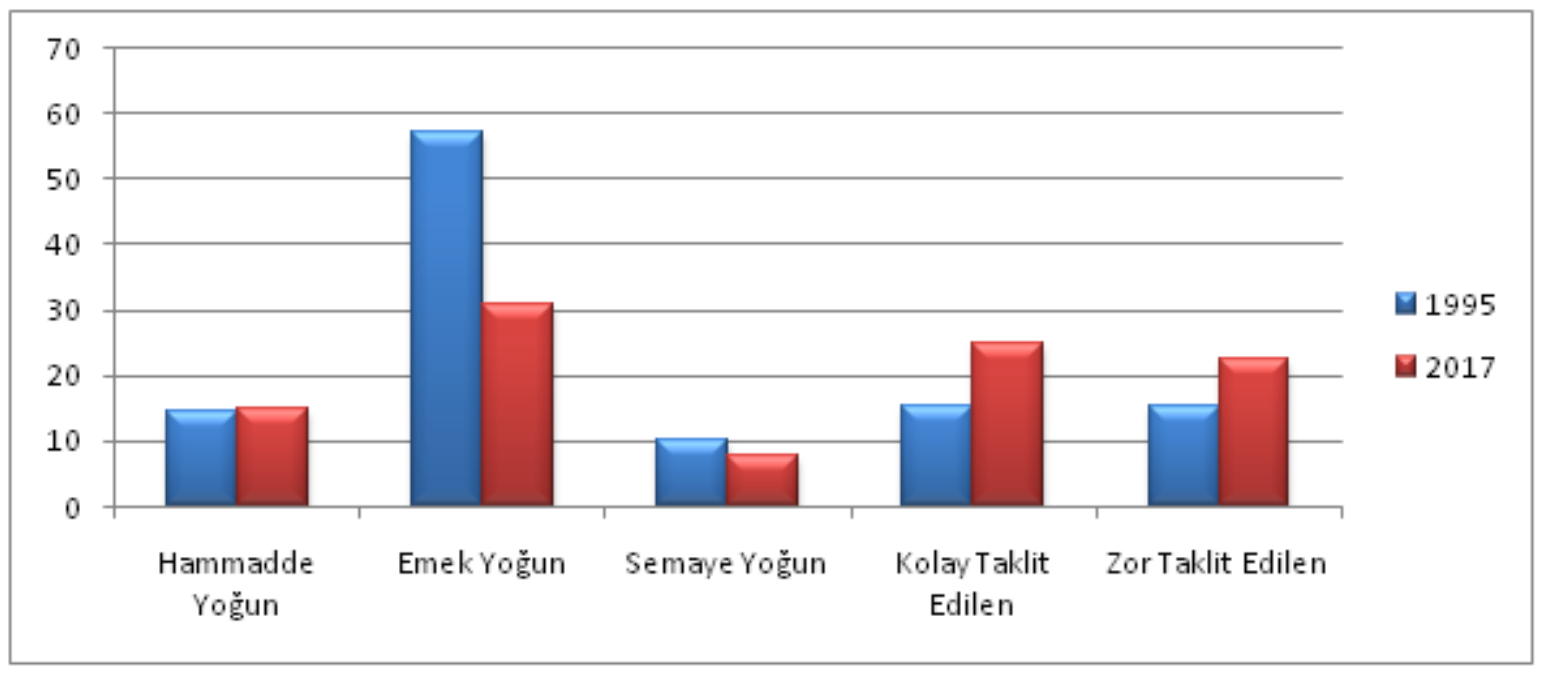

Grafik 4. Çin’in Faktör Donatımına Göre İhracat Payı (\%) $(1995,2017)$ SITC Mal Grupları

Kaynak: Comtrade veri tabanı kullanılarak tarafımızca hazırlanmıştır.

Grafik 4'de Çin ekonomisinin üretim ve ihracatındaki faktör donatımı incelendiğinde, emek yoğun malların toplam ihracat içinde ağırlık teşkil ettiği gözlenmiştir. 1995 yılında Çin'nin toplam ihracatının \%57.2'si emek yoğun malların üretiminden oluşurken, 2017 yılında bu rakamın \%30.8'lere kadar gerilediği gözlenmiştir. Aynı zamanda, özellikle ArGe bazlı malların üretiminde ve ihracatında önemli artışlar gerçekleşmiştir. Ancak emek yoğun sektörlerin Çin ekonomisi için hala vazgeçilmesi kolay olmayan sektörler olduğu ileri sürülmektedir. 


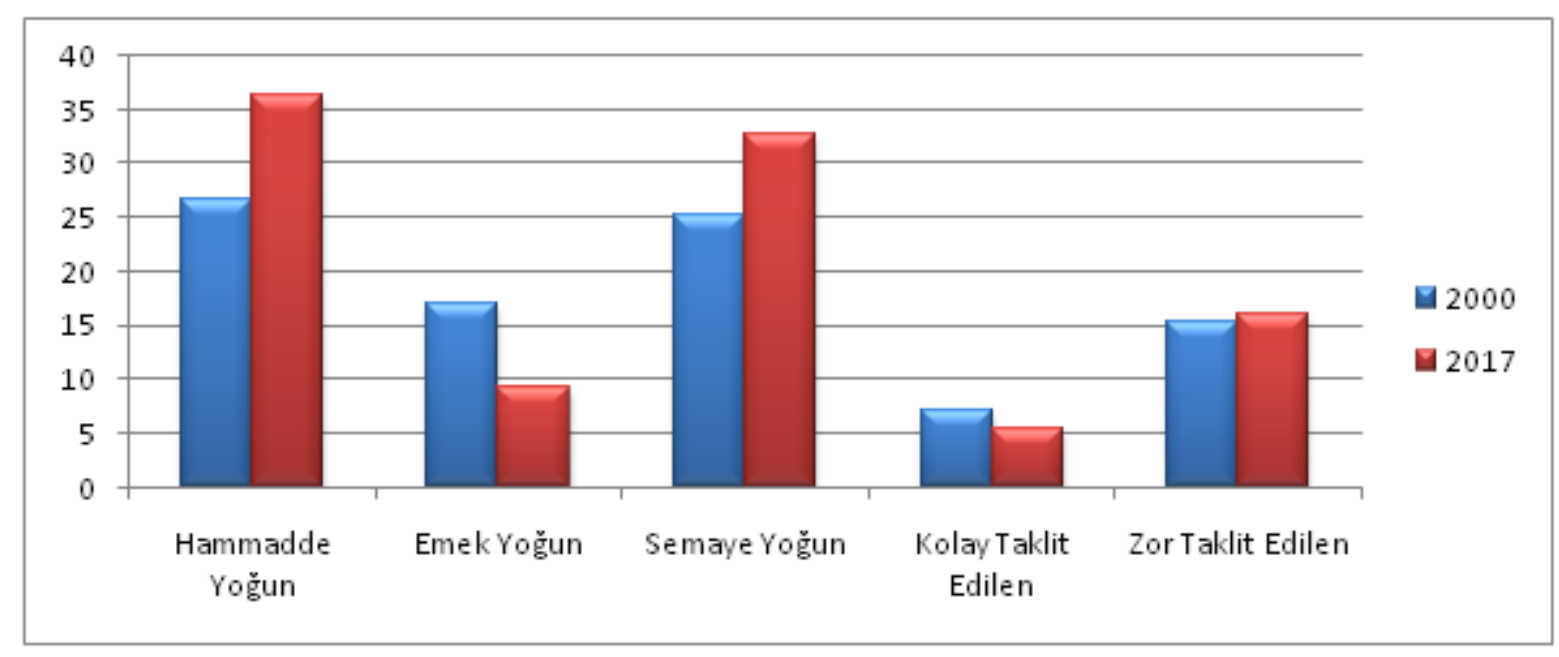

Grafik 5. Güney Afrika’nın Faktör Donatımına Göre İhracat Payı (\%) (2000,2017) SITC Mal Grupları

Kaynak: Comtrade veri tabanı kullanılarak tarafimızca hazırlanmıştır.

Grafik 5'de Güney Afrika ekonomisinin üretim ve ihracatındaki faktör donatımı incelendiğinde, hammadde ve sermaye yoğun malların toplam ihracat içindeki payının görece yüksek olduğu tespit edilmiştir. 2000 yılında Güney Afrika'nın toplam ihracatının \%26'sı civarı hammadde yoğun malların üretiminden oluşurken, 2017 yılında bu rakamın \%36.8'lara kadar yükseldiği gözlenmiştir. Sermaye yoğun malların toplam ihracat içindeki payına bakıldığında, 2000 y1lında \%25.1 düzeyinde seyreden rakamlar, 2017 y1lında 31.8 düzeyine yükseldiği gözlenmiştir.

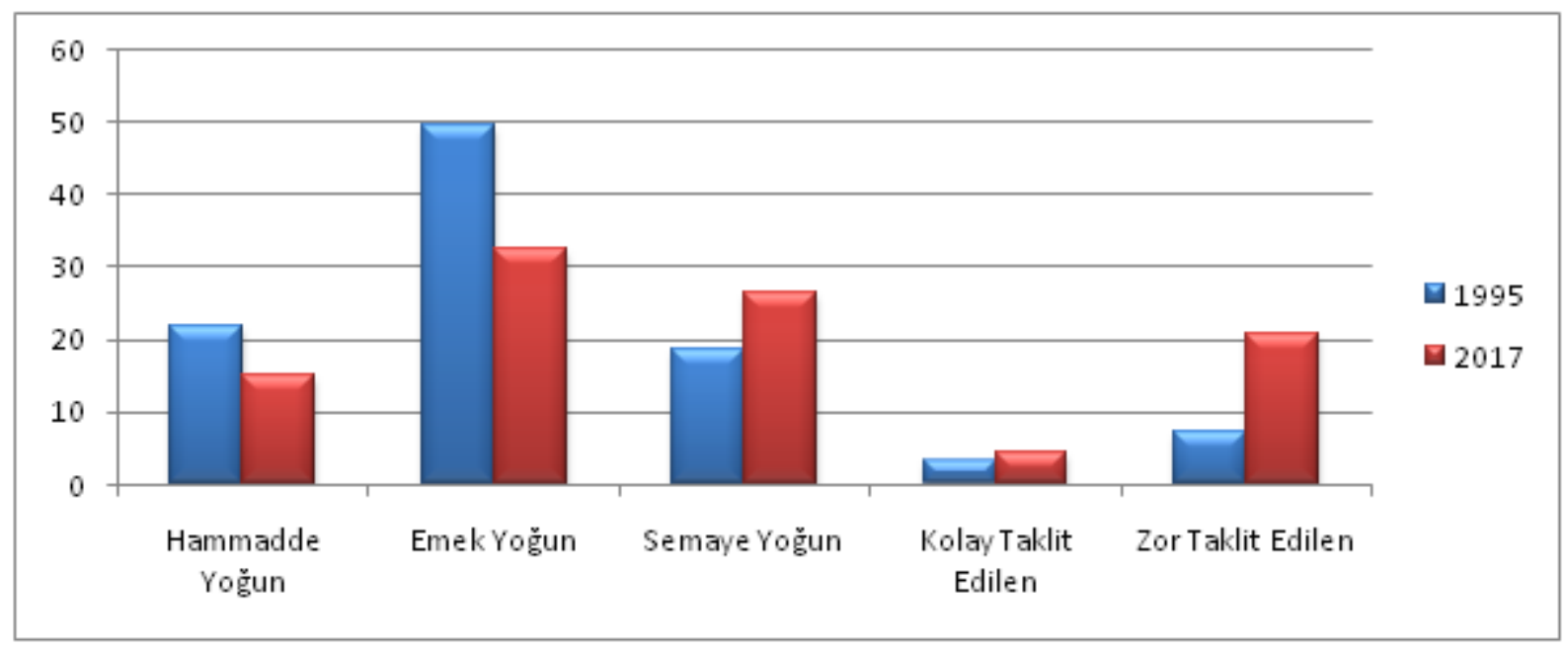

Grafik 6. Türkiye’nin Faktör Donatımına Göre İhracat Payı (\%) (1995,2017) SITC Mal Grupları

Kaynak: Comtrade veri tabanı kullanılarak tarafımızca hazırlanmıştır.

Grafik 6'da Türkiye ekonomisinin üretim ve ihracatındaki faktör donatımı incelendiğinde, emek yoğun malların toplam ihracat içinde ağırlık teşkil ettiği gözlenmiştir. 1995 yılında Türkiye'nin toplam ihracatının \%49.5'i emek yoğun malların üretiminden oluşurken, 2017 yılında bu rakamın \%32.7'e kadar gerilediği gözlenmiştir. Türkiye ekonomisi için emek yoğun malların toplam ihracat içindeki payı düşmesine rağmen, emek yoğun mal üretiminde uzmanlaşan sektörler hala öncü sektörler olma niteliğini korumaktadır. 1995 yılında Türkiye'nin toplam ihracatında en büyük ikinci payı alan Hammadde yoğun malların 2017 yılında dördüncü sırada yer alması çarpıcıdır. Bu durum, Türkiye’nin faktör donatımlarının yıllar itibariyle nispi anlamda değiştiğini ifade etmektedir. Türkiye'nin faktör donatımları açısından bir diğer gelişme, sermaye yoğun ve zor taklit edilen Ar-Ge bazlı malların ihracatının toplam ihracatındaki payının 1995 y1lından 2017 yılına kadar gözlenen yükselme eğilimidir.

BRICS ve Türkiye'nin faktör donatımlarına göre açıklanmış karşılaştırmalı üstünlükleri(rekabet gücü) incelendiğinde, söz konusu ülkelerin ihracatını yaptıkları mal gruplarının gelişiminin benzer sonuçlar doğurduğu gözlenmiştir. Balassa endeksi yardımıyla elde edilen rekabet gücü bulguları aşağıdaki tabloda raporlanmıştır. Tablo 7 , 1995, 2000, 2005, 2010 ve 2017 yıllarına ait SITC teknoloji sınıflandırmasına göre BRICS ve Türkiye ekonomilerinin ihracatlarındaki açıklanmış karşılaştırmalı üstünlüklerini göstermektedir. 
Tablo 7. SITC Teknoloji Sınıflandırmasına Göre BRICS ve Türkiye Ekonomilerinin İhracatlarındaki Açıklanmış

Karşılaştırmalı Üstünlükler (1995, 2000, 2005, 2010, 2017)

\begin{tabular}{|c|c|c|c|c|c|c|c|}
\hline & Tarih & Brezilya & Rusya & Hindistan & Çin & $\begin{array}{l}\text { Güney } \\
\text { Afrika }\end{array}$ & Türkiye \\
\hline \multirow{6}{*}{ 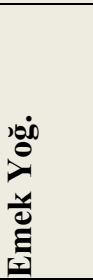 } & 1995 & 0.72 & 0.18 & 2.40 & 2.59 & 1.74 & 2.22 \\
\hline & 2000 & 0.72 & 0.22 & 2.50 & 2.00 & 0.77 & 2.18 \\
\hline & 2005 & 0.57 & 0.15 & 2.18 & 1.76 & 0.67 & 2.02 \\
\hline & 2010 & 0.36 & 0.10 & 1.73 & 1.62 & 0.57 & 1.73 \\
\hline & 2017 & 0.37 & 0.19 & 1.63 & 1.48 & 0.44 & 1.58 \\
\hline & Ort. & 0.54 & 0.16 & 2.08 & 1.89 & 0.83 & 1.94 \\
\hline \multirow{6}{*}{ 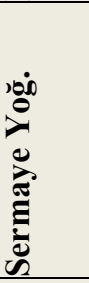 } & 1995 & 1.35 & 1.94 & 0.47 & 0.59 & - & 1.06 \\
\hline & 2000 & 1.54 & 1.67 & 0.51 & 0.45 & 1.60 & 1.15 \\
\hline & 2005 & 1.30 & 1.42 & 0.71 & 0.47 & 2.37 & 1.48 \\
\hline & 2010 & 0.93 & 1.13 & 0.87 & 0.47 & 2.47 & 1.73 \\
\hline & 2017 & 0.88 & 1.24 & 0.82 & 0.41 & 1.88 & 1.53 \\
\hline & Ort. & 1.20 & 1.48 & 0.67 & 0.47 & 2.08 & 1.39 \\
\hline \multirow{6}{*}{ 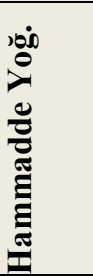 } & 1995 & 2.90 & 4.00 & 1.88 & 1.10 & - & 1.65 \\
\hline & 2000 & 2.59 & 3.70 & 1.62 & 0.58 & 1.68 & 0.84 \\
\hline & 2005 & 2.32 & 3.85 & 1.41 & 0.34 & 1.41 & 0.79 \\
\hline & 2010 & 2.68 & 3.33 & 1.34 & 0.23 & 1.57 & 0.74 \\
\hline & 2017 & 3.81 & 4.65 & 1.61 & 0.26 & 2.32 & 0.97 \\
\hline & Ort. & 2.86 & 3.90 & 1.57 & 0.50 & 1.74 & 0.99 \\
\hline \multirow{6}{*}{ 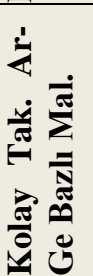 } & 1995 & 0.29 & 0.17 & 0.40 & 0.87 & - & 0.17 \\
\hline & 2000 & 0.49 & 0.22 & 0.44 & 0.99 & 0.38 & 0.27 \\
\hline & 2005 & 0.38 & 0.10 & 0.49 & 1.63 & 0.38 & 0.38 \\
\hline & 2010 & 0.17 & 0.11 & 0.52 & 1.62 & 0.34 & 0.29 \\
\hline & 2017 & 0.17 & 0.11 & 0.69 & 1.45 & 0.34 & 0.23 \\
\hline & Ort. & 0.30 & 0.14 & 0.50 & 1.31 & 0.36 & 0.26 \\
\hline \multirow{6}{*}{ 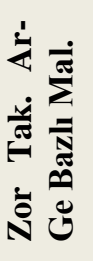 } & 1995 & 0.55 & 0.19 & 0.15 & 0.58 & - & 0.27 \\
\hline & 2000 & 0.82 & 0.23 & 0.19 & 0.70 & 0.39 & 0.43 \\
\hline & 2005 & 0.67 & 0.13 & 0.35 & 0.85 & 0.49 & 0.53 \\
\hline & 2010 & 0.49 & 0.13 & 0.49 & 1.15 & 0.49 & 0.66 \\
\hline & 2017 & 0.55 & 0.16 & 0.55 & 0.86 & 0.62 & 0.66 \\
\hline & Ort. & 0.61 & 0.16 & 0.34 & 0.82 & 0.49 & 0.51 \\
\hline
\end{tabular}

Kaynak: Comtrade veri tabanı kullanılarak tarafimızca hazırlanmıştır.

Tablo 7'de, 1995-2017 yılları arasında BRICS ve Türkiye ekonomilerinin açıklanmış karşılaştırmalı üstünlükleri endeksi (AÇÜ) SITC teknoloji sınıflandırmasına göre raporlanmıştır. Buna göre, emek yoğun mallarda Hindistan, Çin ve Türkiye karşılaştırma üstünlüklerde rekabet avantajına sahipken (AKÜ>1), yıllar itibariyle emek yoğun malların karşılaştırmalı üstünlüklerinde azalma meydana gelmiştir. Söz konusu ülkelerin sermaye yoğun mallarındaki görünüme bakıldığında, Brezilya, Rusya, G. Afrika ve Türkiye ekonomilerinin sermaye yoğun malların üretiminde ve ihracında karşılaştırmalı üstünlüğe(AKÜ>1) sahiptir. Ancak Brezilya ekonomisi, sermaye yoğun mallardaki karşılaştırmalı üstünlüğünü 2010 yılı itibariyle kaybetmiştir(AKÜ<1). Bununla birlikte, Rusya ve Çin sermaye yoğun mallardaki rekabet avantajı yıllar itibariyle gerilemişken, Hindistan ve Türkiye'nin sermaye yoğun malların üretimi açısından nisbi anlamda kazanımlar elde ettiği tespit edilmiştir. Hammadde yoğun mallarda rekabet gücü yüksek olan ülkeler ise Brezilya, Rusya, Hindistan ve Güney Afrika'dır. Ancak, 2017 yılı için Brezilya ve Güney Afrika hammadde yoğun mallarda orta dereceli bir rekabet avantajına $(2<\mathrm{AKÜ}<4)$ sahipken, Rusya'nın güçlü bir rekabet avantajı(4<AKÜ) olduğu gözlenmiştir. Kolay taklit edilen Ar-Ge bazlı malların rekabet gücü görünümü incelendiğinde, Çin ekonomisinin 2000 yılından itibaren bu alanda zayıf üstünlük düzeyinde $\operatorname{de}(1<\mathrm{AKÜ}<2)$ olsa rekabet avantajı sağlamaya başladığı görülmüştür. Zor taklit edilen Ar-Ge bazlı mallarda ise 2010 yılında Çin zayıf üstünlük düzeyinde rekabet avantajı sağlarken, diğer ülkelerin bu tür mal gruplarında karşılaştırmalı üstünlükleri gözlenmemiştir. 


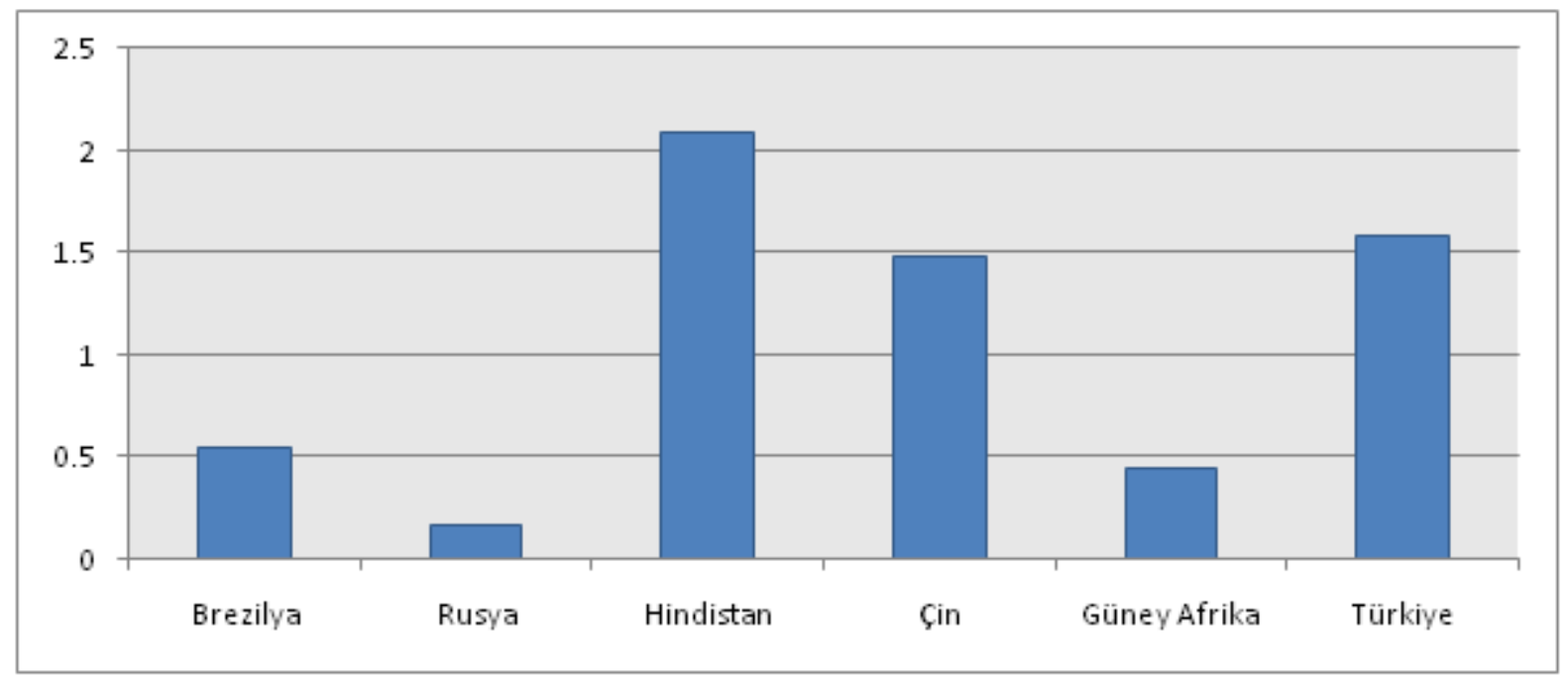

Grafik 7. BRICS ve Türkiye Ekonomilerinin Emek Yoğun Malların İhracatındaki Açıklanmış Karşılaştırmalı Üstünlükleri (Ortalama)

Kaynak: Comtrade veri tabanı kullanılarak tarafımızca hazırlanmıştır.

Grafik 7'de, 1995-2017 yılları arasında ortalaması alınmış BRICS ve Türkiye ekonomilerinin açıklanmış karşılaştırmalı üstünlükleri endeksinin (AÇÜ) SITC teknoloji sınıflandırmasına göre gösterilmiştir. Analiz edilen ülkeler arasında Hindistan, Çin ve Türkiye ekonomilerinin emek yoğun mallarda karşılaştırmalı üstünlüklere(rekabet avantajına) sahip olduğu gözlenmiştir.

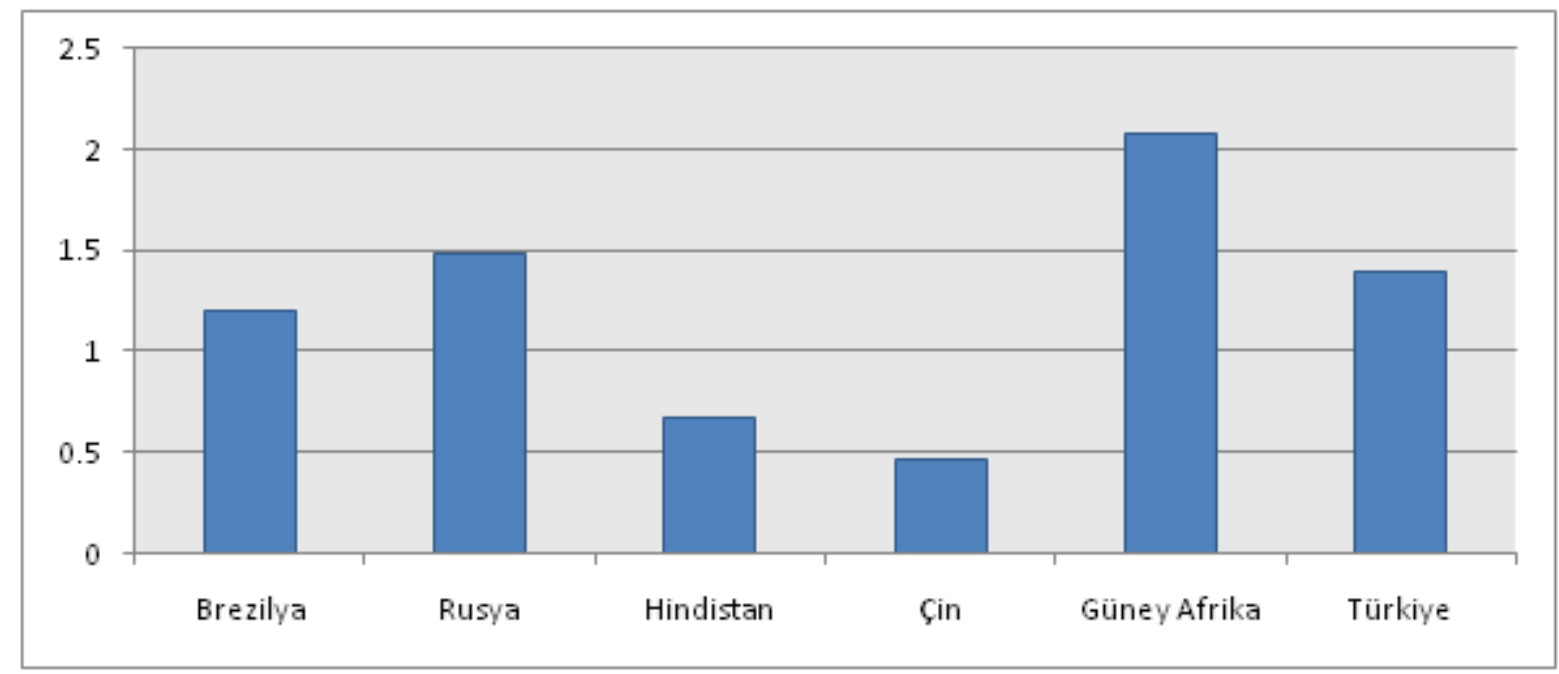

Grafik 8. BRICS ve Türkiye Ekonomilerinin Sermaye Yoğun Malların İhracatındaki Açıklanmış Karşılaştırmalı

$$
\text { Üstünlükleri (Ortalama) }
$$

Kaynak: Comtrade veri tabanı kullanılarak tarafımızca hazırlanmıştır.

Grafik 8'de, 1995-2017 yılları arasında ortalaması alınmış BRICS ve Türkiye ekonomilerinin açıklanmış karşılaştırmalı üstünlükleri endeksinin (AÇÜ) SITC teknoloji sınıflandırmasına göre sermaye yoğun malların rekabet koşulları gösterilmiştir. Analiz edilen ülkeler arasında Brezilya, Rusya ve Türkiye ekonomilerinin sermaye yoğun mallarda zayıf derecede karşılaştırmalı üstünlüklere(rekabet avantajına) sahip olduğu, G.Afrika'nın orta dereceli karşılaştırmalı üstünlüğe sahip olduğu gözlenmiştir. 


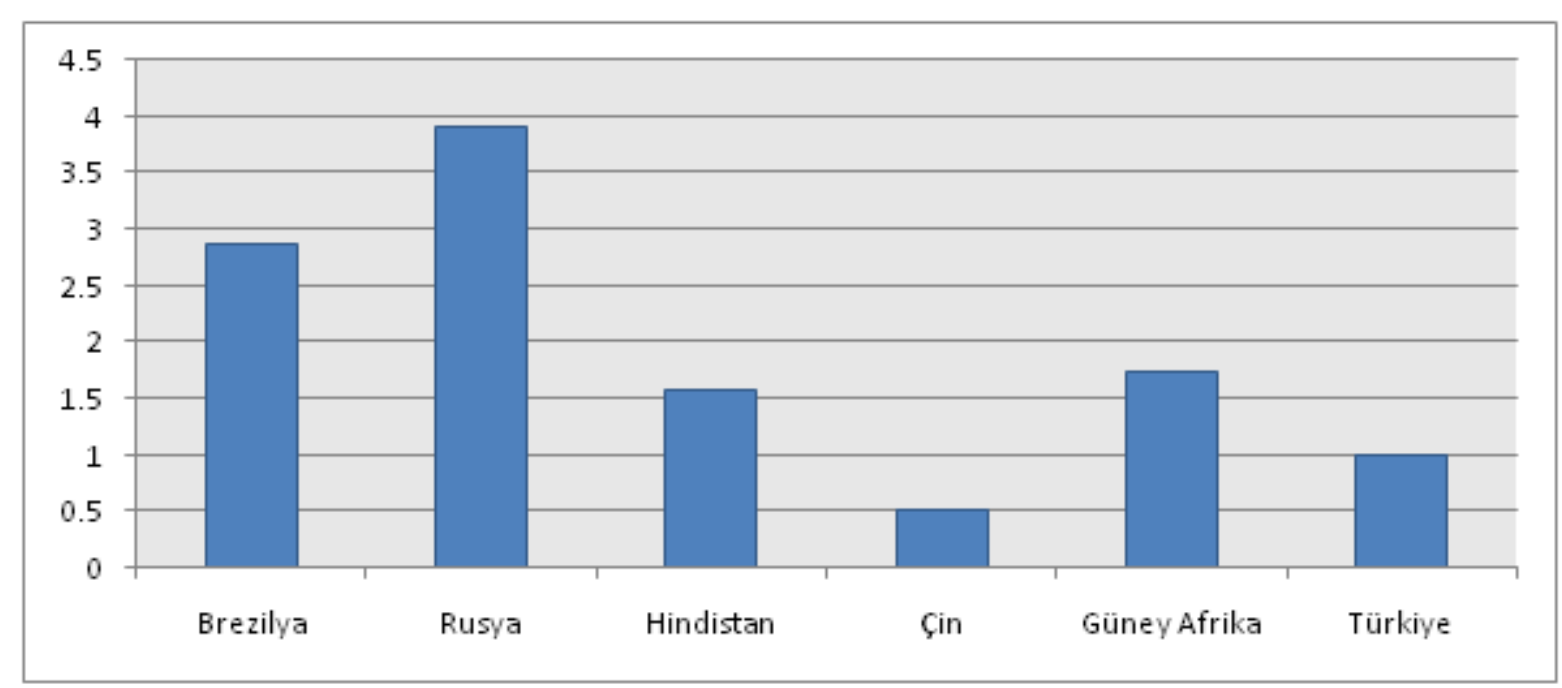

Grafik 9:.BRICS ve Türkiye Ekonomilerinin Hammadde Yoğun Malların İhracatındaki Açıklanmış Karşılaştırmalı

$$
\text { Üstünlükleri (Ortalama) }
$$

\section{Kaynak: Comtrade veri tabanı kullanılarak tarafımızca hazırlanmıştır.}

Grafik 9'da, 1995-2017 yılları arasında ortalaması alınmış BRICS ve Türkiye ekonomilerinin açıklanmış karşılaştırmalı üstünlükleri endeksinin (AÇÜ) SITC teknoloji sınıflandırmasına göre hammadde yoğun malların rekabet koşulları gösterilmiştir. Analiz edilen ülkeler arasında Brezilya ve Rusya’nın hammadde yoğun mallarda orta derecede karşılaştırmalı üstünlüğe (rekabet avantajına) sahip olduğu, Hindistan ve G.Afrika'nın ise hammadde yoğun mallarda düşük dereceli karşılaştırmalı üstünlüğe sahip olduğu gözlenmiştir.

Çalışmada yapılan analizlerde elde edilen bulgulara göre, BRICS ve Türkiye ekonomilerinin kolay ve zor taklit edilen Ar-Ge bazlı malların ihracatındaki açıklanmış karşılaştırmalı üstünlük katsayılarının nispi olarak düşük olduğu görülmektedir. Bu da söz konusu ülkelerin genel olarak Ar-Ge içerikli malların ihracatında rekabet dezavantajına sahip olduğunun göstergesidir. Ancak, Çin bu ülke grupları arasında Ar- Ge içerikli mal ihracatı bakımından karşılaştırmalı üstünlüklerinde görece yükselme trendi sergilemiştir.

\section{Sonuç}

Çalışmada, 1995-2017 yılları arasında BRICS ve Türkiye ekonomilerinin açıklanmış karşılaştırmalı üstünlükleri endeksi (AÇÜ) SITC teknoloji sınıflandırmasına göre raporlanmıştır. Buna göre, emek yoğun mallarda Hindistan, Çin ve Türkiye karşılaştırma üstünlüklerde rekabet avantajına sahipken (AKÜ>1), yıllar itibariyle emek yoğun malların karşılaştırmalı üstünlüklerinde azalma meydana gelmiştir. Ancak emek yoğun sektörler bu ülkelerin (Hindistan, Çin ve Türkiye’nin) rekabet gücünün en yüksek ve karşılaştırmalı üstünlüğe sahip olduğu alanlar olma konumunu korumaktadır.

Söz konusu ülkelerin sermaye yoğun mallarındaki görünüme bakıldığında, Brezilya, Rusya, G. Afrika ve Türkiye ekonomilerinin sermaye yoğun malların üretiminde ve ihracında karşılaştırmalı üstünlüğe (AKÜ>1) sahiptir. Ancak Brezilya ekonomisi, sermaye yoğun mallardaki karşılaştırmalı üstünlüğünü 2010 yılı itibariyle kaybetmiştir (AKÜ<1). Bununla birlikte, Rusya ve Çin için sermaye yoğun mallardaki rekabet avantajı yıllar itibariyle gerilemişken, Hindistan ve Türkiye'nin sermaye yoğun malların üretimi açısından nisbi anlamda kazanımlar elde ettiği tespit edilmiştir.

Hammadde yoğun mallarda rekabet gücü yüksek olan ülkeler ise Brezilya, Rusya, Hindistan ve Güney Afrika'dır. Ancak, 2017 y1lı için Brezilya ve Güney Afrika hammadde yoğun mallarda orta dereceli bir rekabet avantajına $(2<\mathrm{AKÜ}<4)$ sahipken, Rusya'nın güçlü bir rekabet avantajı $(4<\mathrm{AKÜU})$ olduğu gözlenmiştir.

Kolay taklit edilen Ar-Ge bazlı malların rekabet gücü görünümü incelendiğinde, Çin ekonomisinin 2000 yılından itibaren bu alanda zayıf üstünlük düzeyinde $(1<\mathrm{AKÜ}<2)$ olsa da rekabet avantajı sağlamaya başladığ1 görülmüştür. Zor taklit edilen Ar-Ge bazlı mallarda ise 2010 yılında Çin zayıf üstünlük düzeyinde rekabet avantajı sağlarken, diğer ülkelerin bu tür mal gruplarında karşılaştırmalı üstünlükleri gözlenmemiştir.

Çalışmada yapılan analizlerde elde edilen bulgulara göre, BRICS ve Türkiye ekonomilerinin kolay ve zor taklit edilen Ar-Ge bazlı malların ihracatındaki açıklanmış karşılaştırmalı üstünlük katsayılarının nispi olarak düşük olduğu görülmektedir. Bu da söz konusu ülkelerin genel olarak Ar-Ge içerikli malların ihracatında rekabet dezavantajına sahip olduğunun göstergesidir. Çin bu ülke grupları arasında Ar-Ge içerikli mal ihracatı bakımından karşılaştırmalı üstünlüklerinde görece yükselme trendi sergilemiştir. Ancak Türkiye, Ar-Ge bazlı mal ihracatı ve rekabet gücü bakımından söz konusu ülke grubu içinde en kötü konumdan olan ülkelerden biridir. Ar-Ge bazlı mal üretimi özellikle katma değeri yüksek mal üretmek isteyen taraflar açısından hayati önemdedir. BRICS ülkelerinden Çin'in her geçen yıl katma değeri yüksek Ar-Ge bazlı mal ihracının toplam ihracatı içindeki payındaki artış son derece dikkat çekicidir. Bu bağlamda Çin'i, Hindistan takip etmektedir. Hindistan ekonomisi için de Ar-Ge bazlı mal ihracatında görece iyileşmeler tespit edilmiştir. Bu durum, genellikle emek yoğun, niteliksiz ve katma değeri düşük mal ihracında rekabet avantajına 
Çelik, A. / Journal of Yasar University, 2019, 14/55, 339-357

sahibi olan ülkelerin, üretim stratejisileri ve ekonomi politikalarını değiştirdiğine dair önemli emareler sunmaktadır. Türkiye özelinde bakıldığında, Türkiye ekonomisinin de aynı ölçekte ekonomiler olmamalarına rağmen Çin ve Hindistan ekonomilerinin izlediğine benzer bir ekonomi politikası izlemesi gerektiği gözler önüne serilmektedir.

Ülkelerin rekabetçi olma düzeyini belirleyen en önemli parametreler; teknolojik gelişme ve yenilik yapabilme potansiyelidir. Yeni ürün geliştirme, üretim tekniklerindeki buluşlar ya da maliyet avantajı sağlayan yeni üretim süreçleri şeklinde olsun teknolojik gelişmeler, ülkelerin rekabetçi anlamda ileriye sıçratan etmenler haline gelmiştir. Teknolojik yenilik yapma ve geliştirme kapasitesinin ise bir ülkede yapılan araştırma geliştirme (Ar-Ge ) faaliyetleri, nitelikli eğitim yatırımları, özgür düşüncenin tesis edilmesi, hukuk sisteminin düzgün işlemesi ile doğrudan ilişsili olduğu söylenebilir. Esasen büyüme potansiyeli yüksek ekonomilere, rekabet avantajının sürdürülebilirliği toplam ihracat içerisinde ileri teknolojili ürünlerin paylarının artırılmasına bağlı olduğu gözlenmiştir. Dolayısıyla özellikle Türkiye özelinde, uluslararası düzeyde rekabetçi konuma gelmek için Ar-Ge bazlı ürün ihracatını teşvik edecek yatırımların yanı sıra yukarıda sıralanan diğer koşullar çerçevesinde bir toplumsal yaşamın tesis edilmesi gerektiği önerilmektedir. 


\section{KAYNAKÇA}

Aktan, C.C. ve Vural, Y.İ. (2004) Rekabet Gücü ve Rekabet Stratejileri, Ankara, TİSK Yayını Rekabet Dizisi: 3.

Altay, B. ve Gürpınar, K. (2008) “Açıklanmış Karşılaştırma Üstünlükler ve Bazı Rekabet Gücü Endeksleri: Türkiye Mobilya Sektörü Üzerine Bir Uygulama’, Afyon Kocatepe Üniversitesi İI. B.F. Dergisi,Sayı:1, ss. 257-274.

Altıntaş, N. ve Akpolat, A. (2013) “Tekstil Sektöründe Avrupa Birliği ile Türkiye Arasındaki Rekabet Analizi” Kafkas Üniversitesi İktisadi ve İdari Bilimler Fakültesi Dergisi, 4(6): 33-42.

Atik, H.(2005). Yenilik ve Ulusal Rekabet Gücü, Ankara: Detay Yayıncılık

Balassa, B. (1965), "Trade Liberalization and Revealed Comparative Advantage", The Manchester School of Economic and Social Studies, 33, pp. 99-121.

Bağcı E. (2016), 'Türkiye'nin İmalat Sanayi Sektörünün Uluslararası Rekabet Gücü Analizi', Marmara Üniversitesi Íktisadi ve İdari Bilimler Dergisi, Cilt 38 , Say1 1, Haziran 2016, ISSN: 2149-1844, ss. 73-92 DOI: 10.14780/iibd.46308

Bedir A. (2009), Uluslararası Ticarette Fiyata Dayalı Rekabet Gücü İle Endüstri-İçi Ticaret Arasındaki İlişki: Türk İmalat Sanayi Örneği, Ankara Üniversitesi SBE İktisat ABD, Doktora Tezi.

Çakmak, Ö. (2005). Açıklanmış Karşılaştırmalı Üstünlükler ve Rekabet Gücü: Türkiye Tekstil ve Hazır Giyim Endüstrisi Üzerine Bir Uygulama, Ege Akademik Baklş, 5(1): 65-76.

Çivi, E. (2001), '’ Rekabet Gücü: Literatür Taraması', Yönetim ve Ekonomi Dergisi, 8(29): 21-38.

Eroğlu, Ö. ve Özdamar, G. (2006) "Türk İmalat Sanayinin Rekabet Gücü ve Beyaz Eşya Sektörü Üzerine Bir İnceleme" Akdeniz Üniversitesi IBBF Dergisi, 11: 85-104.

Fertö, I. and Hubbard J. L. (2003) Revealed Comparative Advantage and Competitiveness in Hungarian Agri-Food Sectors, The World Economy, Vol: 26, Issue: 2, pp. 247-259.

Granabetter, D. (2016) "Revealed Comparative Advantage Index: An Analysis Of Export Trade In The Austrian District Of Burgerland', Review of Innovation and Competitiveness, Vol: 2, Issue:2, pp. 97-114.

Greenaway, D., C. Milner (1983) “On the Measurement of Intra-Industry Trade”, The Economic Journal, V. 93 , No: 372.

Hiranya K. Nath and Binoy Goswami (2018), “India’s Comparative Advantages in Services Trade”, Eurasian Economic Review, 10.1007/s40822-018-0098-0, 8, 2, pp.323-342.

Jeremiás Máté Balogh and Attila Jámbor (2017) The Global Competitiveness of European Wine Producers, British Food Journal, 119, 9, (2076).

Kara, O., Erkan, B., (2012) “Türkiye’nin Emek Yoğun Mal İhracatındaki Karşılaştırmalı Üstünlüklerin Makro Ekonomik Büyüklüklerle İlişkisi”, Abant İzet Baysal Üniversitesi İ̈F Ekonomik ve Sosyal Araştırmalar Dergisi, Cilt:7, Y1l:7, Sayı:1.

Kibritçioğlu, A (ed)., (1996), Uluslararası Rekabet Gücüne Kavramsal Bir Yaklaşım”, Uluslararası (Makro)íktisatOkumalar, Ankara: 72, TDFOB Yayıncılık.

Kösekahyaoğlu, L. Ve Özdamar, G. (2011) “Türkiye, Çin ve Hindistan’ın Sektörel Rekabet Gücü Üzerine Karşılaştırmalı Bir İnceleme" Uludağ Üniversitesi İktisadi ve İdari Bilimler Fakültesi Dergisi, 30(2): 29-49.

Porter, M.E., (1990a), The Competitive Advantages of Nations, The Macmillian Press Ltd., London and Basingstoke,http://www.economie.ens.fr/IMG/pdf/porter_1990_the_competitive_advantage_of_nations.pdf.

Seymen D. (2009), Türkiye'nin Dış Ticaret Yapısı ve Rekabet Gücü, DË̈̈ Yayınlarl, ISBN 9789754412628.

Şahin D. (2015), 'Türkiye'nin Emek Yoğun Mallarda Rekabet Gücünün Ölçümü: BRIC Ülkeleri ile Karşılaştırmalı Analiz’', Çankırı Karatekin Üniversitesi Sosyal Bilimler Enstitüsü Dergisi, Cilt: 6, Sayı: 2.

Şahinli M. (2011), Açıklanmış Karşılaştırmalı Üstünlükler Endeksi: Türkiye Pamuk Endüstrisi Üzerine Bir Uygulama, SÜ İBF Sosyal ve Ekonomik Araştırmalar Dergisi, Cilt: 15, Sayı: 21.

Utkulu, U., Seymen, D., (2004)"' Revealed Comparative Advantage and Competitiveness: Evidence for Turkey vis-ą-vis the EU/15',Paper was presented at the European Study Group 6th Conference, ETSG 2004.

Vollrath, Thomas L. (1991): “A Theoretical Evaluation of Alternative Trade Intensity Measures of Revealed Comparative Advantage', Weltwirtschafliches Archiv, 127, 265-279.

Yalçınkaya H., Çılbant C., Erataş Filiz, Hartoğlu, D. (2014), Açıklanmış Karşılaştırmalı Üstünlükler Ekseninde Rekabet Gücünün Analizi: Türk-Çin Dış Ticareti Üzerine Bir Uygulama, Yönetim ve Ekonomi Araştırmaları Dergisi, Say1:24, Doi: http://dx.doi.org/10.11611/JMER294

UN Comtrade Database http://comtrade.un.org/data/. 